University of Rhode Island

DigitalCommons@URI

Open Access Dissertations

2017

\title{
The High School and Community College Experiences of Immigrant-English Language Learners
}

Pamela Murillo

University of Rhode Island, pamelavmurillo@gmail.com

Follow this and additional works at: https://digitalcommons.uri.edu/oa_diss

\section{Recommended Citation}

Murillo, Pamela, "The High School and Community College Experiences of Immigrant-English Language Learners" (2017). Open Access Dissertations. Paper 677.

https://digitalcommons.uri.edu/oa_diss/677

This Dissertation is brought to you for free and open access by DigitalCommons@URI. It has been accepted for inclusion in Open Access Dissertations by an authorized administrator of DigitalCommons@URI. For more information, please contact digitalcommons-group@uri.edu. 
THE HIGH SCHOOL AND COMMUNITY COLLEGE EXPERIENCES OF IMMIGRANT-ENGLISH LANGUAGE LEARNERS

BY

PAMELA MURILLO, M.A.

\begin{abstract}
A DISSERTATION SUBMITTED IN PARTIAL FULFILLMENT
OF THE REQUIREMENT FOR THE DEGREE OF

DOCTOR OF PHILOSOPHY

IN PSYCHOLOGY
\end{abstract}

UNIVERSITY OF RHODE ISLAND

2017 
DOCTOR OF PHILOSOPHY DISSERTATION

OF

PAMELA MURILLO

APPROVED:

Dissertation Committee:

Major Professor Margaret Rogers

Paul Florin

JoAnn Hammadou

Nasser H. Zawia

DEAN OF THE GRADUATE SCHOOL

UNIVERSITY OF RHODE ISLAND

2017 


\begin{abstract}
The purpose of the present study was to examine the educational experiences of Hispanic immigrant-English Language Learners (ELLs) who are graduates of the International High Schools and attended and graduated from a community college. The study focuses on the International High School experiences that seem to foster community college readiness. Moreover, the study focuses on supports and challenges experienced by these individuals, the implications of their second language abilities during their time at their community college, and the reason(s) many Hispanic immigrant-ELLs stop at the Associate's degree and do not continue through to the bachelor's degree. Twelve International High School graduates participated in the study. Qualitative methods were employed and data obtained through semi-structured interviews were analyzed using content analysis.
\end{abstract}

The results showed that participants had a generally good experience at their International High School, and that they found helpful and supportive individuals such as teachers and classmates that helped them get through their high school education. In addition, International High Schools prepared participants for community college through academic and language learning related activities. Many participants communicated that the International High Schools provided them with a general preparation for college, including the opportunity to take college courses and participate in internships. Participants also communicated that while in community college, they received support and encouragement from academic programs as well as from faculty/professors. However, the most commonly identified challenge experienced by participants were negative interactions with professors and staff at their community college. 
Furthermore, the majority of International High School graduates communicated that their second language abilities were helpful/beneficial during their community college years because it helped them academically, and it also helped increase their social interactions with other Spanish-speaking students. Participants also shared their thoughts regarding the reason(s) many Hispanic immigrant-ELLs may stop at the Associate's degree and do not continue through to a baccalaureate degree. The majority of participants felt that the main reasons many Hispanic immigrant-ELLs do not continue through to a baccalaureate degree is because of financial reasons, and because they have familial obligations that impede them from continuing their education further. In providing advice for other immigrant students whose native language is not English to help them get through community college, almost all of the participants provided general encouragement, as well as advice to make use of resources in their community college - including the importance of asking for help. 


\section{ACKNOWLEDGEMENTS}

First and foremost, I would like to express my sincerest gratitude to my major professor, Dr. Margaret Rogers, who has been an extraordinary mentor to me over the past five years. Dr. Rogers has guided me throughout my graduate education and has always shown me her unwavering support. She has been my biggest cheerleader in graduate school, always believing in me, even during times when I did not believe in myself. She has also encouraged and inspired me to achieve my dreams every step of the way. I could not have imagined having a better advisor and mentor for my Ph.D. study.

I would also like to thank my committee members, Dr. JoAnn Hammadou and Dr. Paul Florin for their continued support and enthusiasm towards my project. Thank you for your guidance, your encouragement, and for your thoughtful contributions to my research. A special thank you also goes to all the International High School graduates that participated in this study. Thank you very much for sharing your experiences with me. Without you this project could not have been possible. Also, a big thank you to the undergraduate students who helped me transcribe and code each interview. You are all truly amazing!

Finally, I would like to say an extra special thank you to my parents, my brother, and my grandmother for their unconditional love, endless sacrifices, and words of wisdom. Thank you for always reminding me that dreams come true. You guys are my rock. Without you I would not have been able to be the first in the family to obtain a college degree, and now a doctoral degree. Papito, Mamita, Alla, Gustavito, we did it! 


\section{DEDICATION}

I dedicate this project to my amazing and hardworking parents, Martha and Gustavo Murillo, who immigrated from Honduras in search of a better life for us. This is for all the obstacles we had to overcome as an undocumented family, for all the times we were told we did not belong here, and for the countless times we had to prove ourselves to others. I will be forever thankful for all the sacrifices you made for me, and most importantly, for telling me, “tu puedes hija!” every time I thought I couldn't. 


\section{TABLE OF CONTENTS}

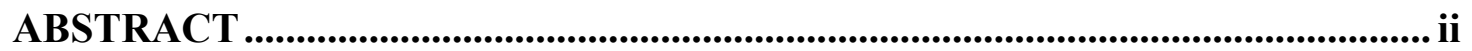

ACKNOWLEDGEMENTS................................................................................ iv

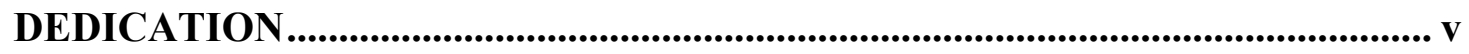

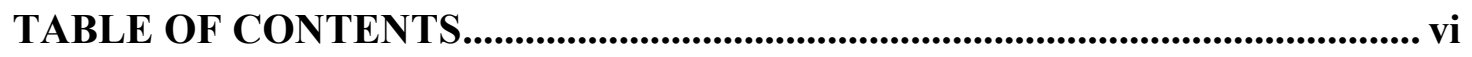

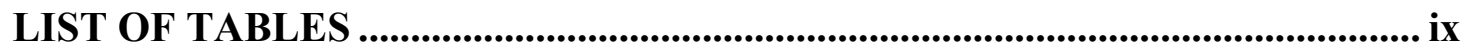

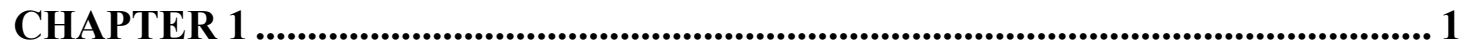

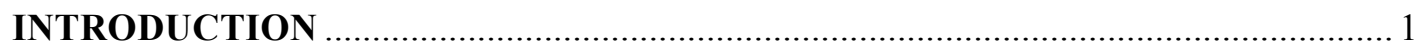

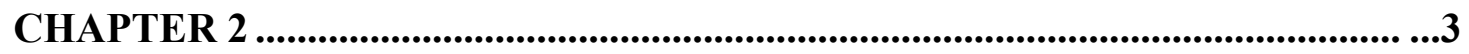

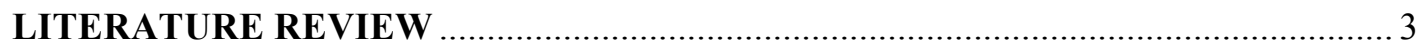

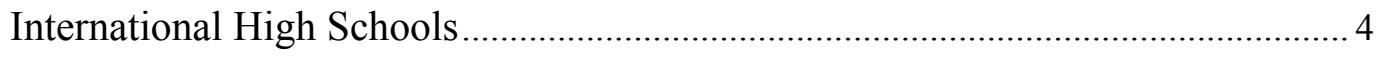

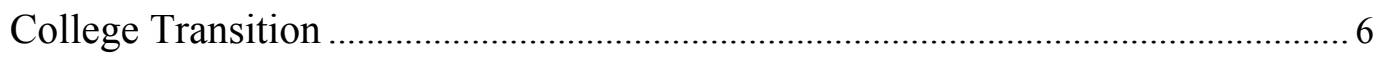

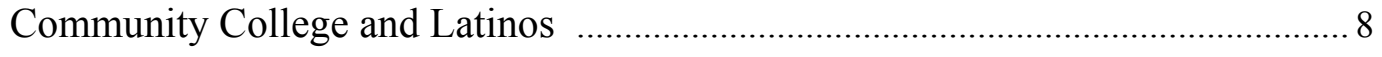

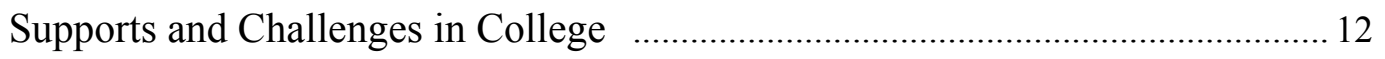

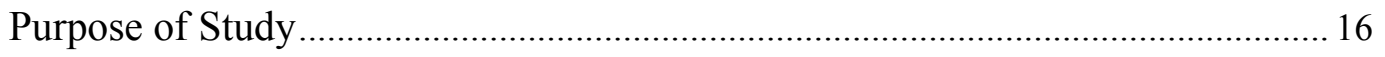

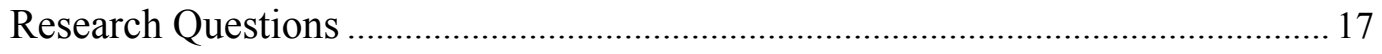

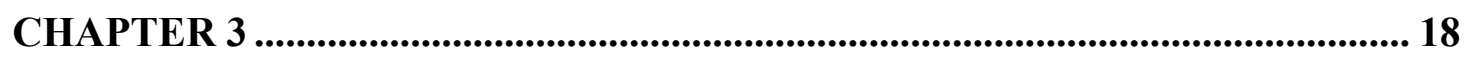

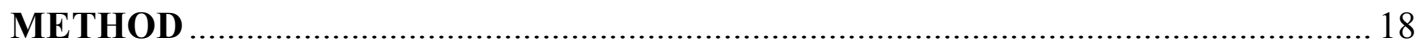

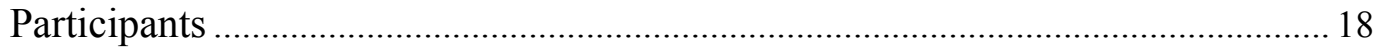

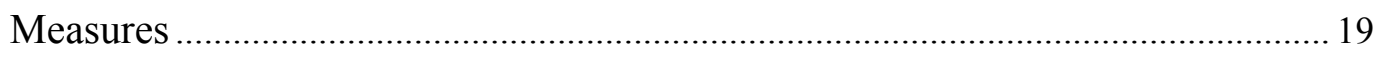

Demographic and Personal Background Questions ................................................ 19

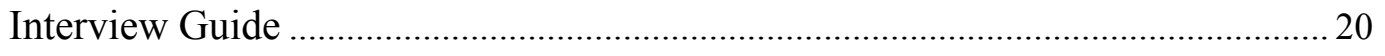


Procedure

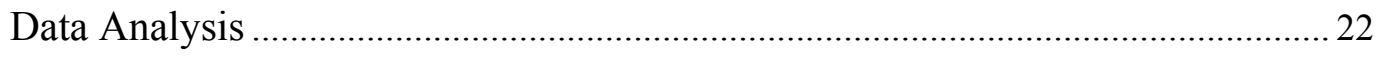

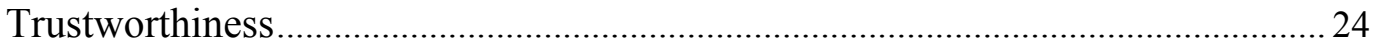

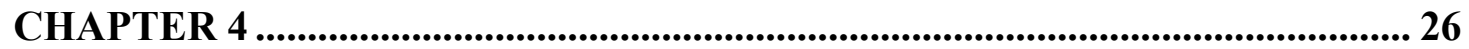

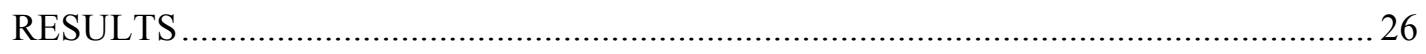

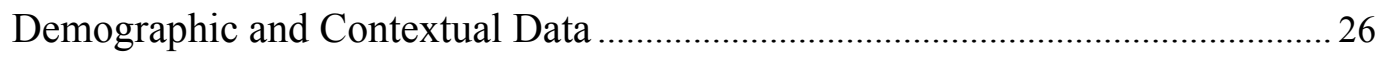

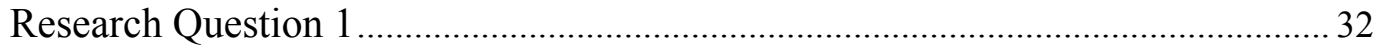

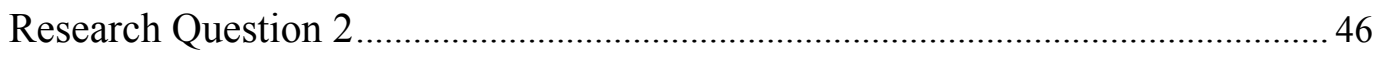

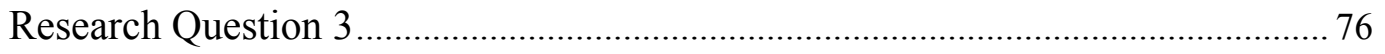

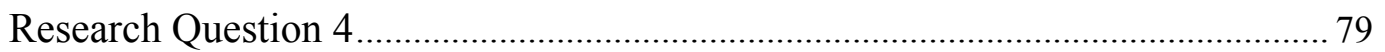

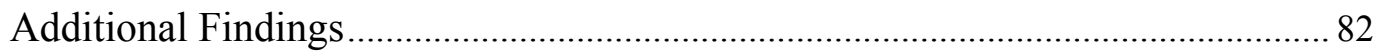

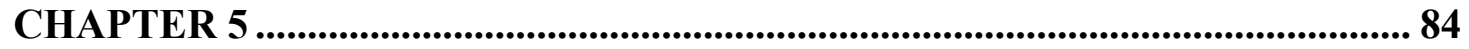

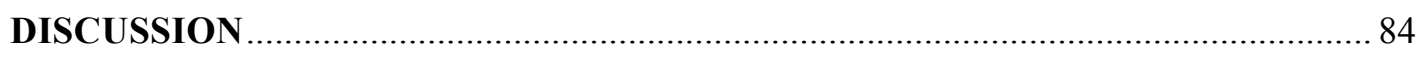

Educational Experiences at the International High Schools .................................. 84

Educational Experiences During Community College .......................................... 89

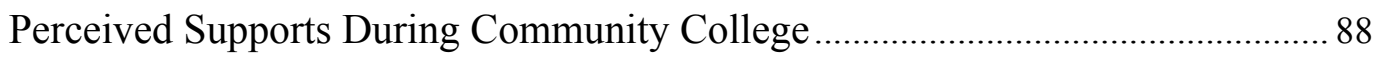

Perceived Challenges During Community College …............................................ 89

Implications of Second Language Abilities .......................................................... 89

Reasons Hispanic Immigrant-ELLs May Stop at the Associate's Degree...........90

Recommendations to Other Immigrant-ELLs...............................91

Limitations and Methodological Considerations ...............................99

Directions for Future Research ............................................93 
Appendix A Demographic and Personal Background Questions..................97

Appendix B Interview Guide.....................................................99

Appendix C Cover letter to Principals and Teachers.............................102

Appendix D Cover Letter to Participants........................................104

Appendix E Informed Consent ........................................................................... 106

Appendix F Statement on Diversity in Research ............................................. 109

Appendix G Facebook Post ........................................................................ 110

Appendix H The Internationals Teachers' Preparation............................111

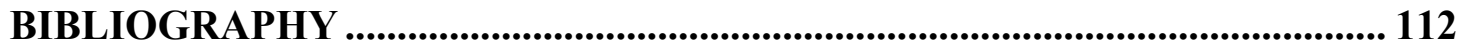




\section{LIST OF TABLES}

TABLE

PAGE

Table 1. Background Information of International High School Graduates. 18

Table 2. Participants' Formal Education in Home Country and Interruption in Education. .26

Table 3. Personal Background Information of International High School Graduates.

Table 4. Community College Information of International High School Graduates...29

Table 5. Reason(s) Participants Attended a Community College........................30

Table 6. Participants' Current Occupation..................................... 31

Table 7. Experiences at the International High Schools............................ 32

Table 8. College Preparation by International High Schools.......................35

Table 9. Messages Received at the International High Schools about College.........37

Table 10. Skills Acquired that Contributed to College Completion ...................39

Table 11. Advice Received at International High School about College .............42

Table 12. Reasons Why the International High Schools had High College

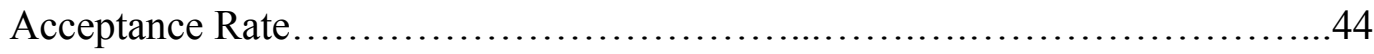

Table 13. Ways High School was Different from College.........................46

Table 14. English Skills in High School and College............................49

Table 15. Supports Experienced by Participants While They Were in College ........53

Table 16. Top Things or People that Helped Keep Participants in College...........55

Table 17. Type of Help Participants Received in College.........................57

Table 18. Help Navigating the College System.....................................59 
Table 19. Ways Participants' were Helped to Navigate College.....................61

Table 20. Mentorship Received in College.................................62

Table 21. Examples of Type of Mentorship Received............................63

Table 22. Participants' Connections with Professors............................65

Table 23. Examples of how Participants Connected with Professors................66

Table 24. Perceived Challenges Experienced by Participants during College..........68

Table 25. Things that Most Hindered Participants during College.....................71

Table 26. Ways Second Language Abilities Helped/Hindered Participants During

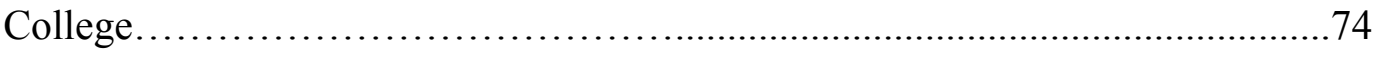

Table 27. Reasons Hispanic Immigrant-ELLs May Stop at the Associate's Degree...77

Table 28. Recommendations Provided by Participants to Help Students Succeed in

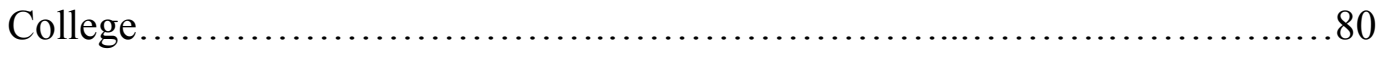

Table 29. Additional Findings........................................... 82 


\section{CHAPTER 1}

\section{INTRODUCTION}

Immigrant students are the fastest growing student population in the United States (U.S.) (Suárez-Orozco, Suárez-Orozco, \& Todorova, 2008). By 2050, it has been estimated that more than one-third of the country's school children younger than 17 will either be immigrants themselves or the children of at least one parent who is an immigrant (Pew Research Center, 2008). Therefore, it has been estimated that the education, training, and transition to the labor market of immigrants and the children of immigrants will increase in importance over the next decade (Baum \& Flores, 2011). However, it is also imperative to consider the current political climate in the U.S. and ways in which President Trump's administration is having a direct yet undesirable impact on millions of immigrants and their families. At present, it is difficult to predict which of the administration's positions on immigration will be instituted, but it is possible that previous estimates suggesting growth will be curbed. For immigrant students in higher education the present administration's statements about their status have placed many questioning their ability to stay and complete their degrees. Thus, it is crucial to highlight the promise of higher education for this population as well as to provide educators and higher education institutions with valuable information on how to better meet the needs of these students.

The International High Schools are a group of public high schools that successfully serve immigrant-English Language Learners (ELLs) who recently arrived in the U.S. Their work is based on a unique approach to educating an immigrant population that combines the integration of language and academic content while 
building student capacity for integration into American society (Internationals Network Organization, 2016). The International High Schools ensure that all students attending the schools have access to a high quality high school education that prepares them for college, thereby increasing their opportunities for success in the U.S. (Internationals Network Organization, 2016). In addition, International High Schools are known to be aware of the many obstacles immigrant-ELL students experience after they graduate high school and begin their college education. Many immigrant-ELLs enroll in community colleges, yet little data is available about their community college experiences.

The purpose of the present study was to examine the educational experiences of Hispanic immigrant-ELLs who are graduates of the International High Schools. The study focuses on the International High School experiences that seem to foster community college readiness, the supports and challenges experienced by these individuals, the implications of their second language abilities during their community college years, and the reason(s) many Hispanic immigrant-ELLs stop at the Associate's degree and do not continue through to the bachelor's degree.

Overall, the intent of this study was to extend the limited research on immigrant students and ELLs by providing valuable information regarding their community college readiness and community college experiences. A secondary goal was to bring attention to the realities of educational opportunities available to immigrant-ELLs in both high school and community college in order to help improve the educational opportunities for this vulnerable, yet complex group of students. 


\section{CHAPTER 2}

\section{LITERATURE REVIEW}

On average, more than one million immigrants enter the U.S. per year, accounting for $12.45 \%$ of the population (U.S. Census Bureau, 2008). By 2030, the immigrant population will make up $18 \%$ of the U.S. labor force (Lowell, 2006), thus educating immigrants and their children has become increasingly important. According to Conway (2014), the U.S. economy has grown into a "knowledge" economy with service jobs demanding technical and informational skills. Consequently, more jobs than ever are mandating a college degree (Conway, 2014).

The National Center for Education Statistics (2007) reports that the gap between high school and college graduates' earnings has increased significantly, such that college graduates can expect to earn almost $60 \%$ more than high school graduates. Many immigrants view higher education as an important means to improve their socioeconomic status and further their assimilation into the U.S. culture (SuárezOrozco et al., 2008; Szelenyi \& Chang, 2002). Indeed, previous research has shown that immigrant students value education, and they tend to have high expectations for higher education compared to their native-born counterparts (Goyette \& Xie, 1999; Hao \& Bronstead-Bruns, 1998; Portes \& Rumbaut, 1996; Rumbaut \& Portes, 2001; Wells, 2010). However, immigrant students may lack the academic preparation necessary for college, have limited resources, and have limited English skills, factors that may impede their access to and success in higher education (Conway, 2014). Given the high demand for advanced skills and training in today's society, the importance of educating immigrants and their children cannot be understated. 


\section{International High Schools}

In large urban cities such as New York, immigrants or the children of immigrants account for more than half of the population (Jensen \& Chitose, 1994). About $40 \%$ of New York City students are considered ELLs, with Spanish being the most frequently spoken language (New York City Department of Education, 2013). According to Fine, Stoudt, and Futch, (2005) and Fine, Jaffe, Pedraza, Stoudt, and Futch (2007) the four-year high school graduation rate for ELLs in New York City is as low as $30.3 \%$. In contrast, the graduation rate for non-ELLs in New York City is 64.7\% (New York City Department of Education, 2013). But in comparison to the majority of New York City high schools, within New York exists a small group of public high schools (Internationals) that provide quality educational support to recently arrived immigrants. The International High Schools serve a population of immigrants who come from 119 countries and speak over 90 languages (Internationals Network for Public Schools, 2016). Students attending International High Schools are in the country four years or less and score in the bottom quartile on English language tests at the time of admission (Internationals Network for Public Schools, 2016). Additionally, many have had interrupted formal education due to economic, social, or political factors, and have been separated from at least one parent during their family's migration to the U.S. (Internationals Network for Public Schools, 2016).

The International High Schools started in 1985 with the founding of their first high school on the campus of LaGuardia Community College (Internationals Network for Public Schools, 2016). In response to the numerous educational challenges faced by recently arrived immigrants in public school districts, the International High School 
at LaGuardia was designed to provide quality education for these students (Internationals Network for Public Schools, 2016). Currently, the International High Schools serve approximately 6,000 students annually, and comprise of a network of 19 public high schools in New York, California, Virginia, and Washington, D.C. (Internationals Network for Public Schools, 2016).

The International High Schools are designed to help recently arrived immigrant-ELLs stay in school, graduate from high school, and attend and complete college. Within the International High Schools' Network, every teacher teaches language as well as academic content and skills (for more information regarding the preparation of teachers at International High Schools see Appendix H). The educational process takes place in heterogeneous classrooms in which students are organized in diverse clusters based on age, grade, academic ability, native language, and English language proficiency (Internationals Network for Public Schools, 2016). These clusters are interdisciplinary and rigorous, and were created based on the idea that students' proficiency in a second language is a valuable resource when achieving academic, professional, and social success in the U.S. (Internationals Network for Public Schools, 2016). The International High Schools create a close-knit, nurturing community that embraces students' native language(s) and culture while helping them adjust to the U.S.'s educational system (Internationals Network for Public Schools, 2016).

While there are numerous approaches to ELL instruction, International High Schools are an important model that have shown to be both successful and adaptable in teaching recently arrived immigrant-ELLs (Kessler, 2009). In a study of the first 
three schools that Internationals opened in New York City, the International High Schools had a 4-year graduation rate of $88.7 \%$, while New York City students classified as ELLs had a 49.6\% 4-year graduation rate (Fine et al., 2005). Additionally, Fine et al. (2005) found that more than $90 \%$ of International graduates were accepted to colleges upon their high school graduation.

Unfortunately, data on immigrant students' educational experiences is scarce. In fact, there is currently no research regarding the community college experiences of students who graduated from the International High Schools. How prepared do International High School graduates feel for a community college? What happens after these students graduate high school and attend bigger and more demanding institutions such as community colleges? Given that the transition to college is a critical period for all students, it is important to note that once students graduate from the International High Schools many may enter institutions of higher education that are not prepared to educate such a diverse and challenging group (Nathan, 2005).

\section{College Transition}

The transition to college is a critical period for immigrant students characterized by challenges in academic, cultural, psychological, and social adjustment (Chickering \& Reisser, 1993). Immigrant students often lack the academic preparation for college, have a need for remediation in English as a second language (ESL), and have limited financial resources (Conway, 2010). In addition, when immigrant students transition to college, their academic adjustment becomes an important contributing factor to their persistence. Some of these academic adjustments include how well they meet academic expectations, understand educational demands, 
motivate themselves to continue college, and how satisfied they feel with their academic performance and college environment (Baker \& Siryk, 1984, 1989; Clark, 2005; Pascarella \& Terenzini, 2005; Tao, Dong, Pratt, Hunsberger, \& Pancer, 2000). Additionally, research has shown that institutional agents such as faculty, staff, and peers play a fundamental role in the persistence and academic success of these students (Teranishi, Suárez-Orozco, \& Suárez-Orozco, 2011).

The mission of the International High Schools is to ensure that recently arrived immigrants have access to a quality high school education that prepares these students well for college (Internationals Network for Public Schools, 2016). The International High Schools are known for their responsiveness to academic and emotional challenges such as those students experience upon matriculation to college. A study conducted by Jaffe-Walter and Lee (2011) revealed the structural and cultural factors that support college-going for recently arrived immigrant students attending International High Schools. Results from their study showed that academic preparation, social capital, and financial resources are key factors affecting students' entry to higher education. Additionally, Jaffe-Walter and Lee (2011) found that the institutional culture and structure of the International High Schools is very focused on college access. The International High Schools create instructional teams to provide students with access to relationships with several adults in the schools, and with a challenging and culturally sensitive curriculum (Jaffe-Walter \& Lee, 2011).

It is important to recognize that recently arrived immigrants like those at the International High Schools face numerous challenges that may affect college persistence and attainment. The International High Schools make significant efforts to 
create safe environments for these students, but when these students graduate from high school many may struggle with the ongoing challenges presented by their immigration status, do not have sufficient knowledge of the college system, have limited financial resources, and possibly limited English skills (Jaffe-Walter \& Lee, 2011). The aim of the present study was to examine the high school and community college experiences of International High School graduates to better understand the factors that may contribute to their college readiness and community college persistence and attainment. The intent is to extend the limited research on Hispanic immigrant ELLs by providing important information that will hopefully help improve the educational experiences of these students at the high school and community college level.

\section{Community Colleges and Latinos}

For many immigrant students, the first exposure to higher education will be at a community college (Conway, 2010). According to Gray and Vernez (1996), immigrants were $20 \%$ more likely than their native born peers to begin their higher education at a community college. Community colleges have often served as a stepping-stone to educational and economic opportunities for immigrant students by providing critical pathways to postsecondary education (Wisell \& Champanier, 2010). Additionally, community colleges play a significant role in educating immigrant students because they provide low cost tuition, open access admission, flexible class schedules, and a wide range of curricular programs including the development of basic skills such as reading, writing, and mathematics (Cohen \& Brawer, 2003).

Educational attainment among Latinos has become very important due to the 
group's growth in the nation's K-12 schools and colleges (U.S. Census Bureau, 2010). According to the U.S. Census Bureau (2010), the growth of our nation's Latino population has increased dramatically over the last couple of decades. However, almost half of Latinos ( $47 \%$ female and $41 \%$ male) over the age of 25 do not have a high school diploma (U.S. Census, 2007). In addition, only about 13\% of Latinos in comparison to $37 \%$ Whites had a bachelor's degree by age 29 in 2010 (U.S. Census Bureau, 2010). Even though data on immigrant-origin students enrolled in community colleges is limited (Szelenyi \& Chang, 2002), a report by the U.S. Department of Education (2006) shows that higher percentages of foreign born Hispanic immigrant undergraduates enrolled in community colleges (51\%) in 2007-2008, compared with $44 \%$ of all undergraduates representing all other ethnicities. Hagy and Staniec (2002) examined the postsecondary enrollment decisions of immigrant and U.S. born students using data from a National Educational Longitudinal Study. They found that among Latino immigrants who went to college, $57.9 \%$ attended community colleges or vocational programs in comparison to $50.5 \%$ of U.S. born Latinos who went to college (Hagy \& Staniec, 2002).

Education at every level is important and beneficial, but education at the college level is particularly crucial for the upward mobility and economic success of the immigrant population (Conway, 2010). Community colleges, as part of their mission, are expected to be accessible to all students, whereas 4-year college institutions may limit enrollment to those who can meet certain academic standards (Conway, 2010). Moreover, community colleges play an important role in educating disadvantaged and less academically prepared students, including ethnic and racial 
minority students, first generation college students, and students from low income backgrounds (Teranishi et al., 2011). Serving 43\% of all U.S. undergraduates (U.S. Department of Education, 2012a), community colleges attract more immigrant students than any other type of institution (Teranishi et al., 2011). Nationwide, two thirds of Latino students seeking higher education start out in community colleges (Solórzano, Rivas, \& Velez, 2005). However, Latino students earn Associate degrees and transfer to four-year colleges at rates below those for non-Latino students (Leinbach \& Bailey, 2006). For example, 32.8\% of native-U.S. born Latino students who started in a CUNY community college obtained an Associate's degree or transferred within 12 years, compared to $37.2 \%$ of U.S. born non-Latino students. Similarly, 37\% of Latino immigrants obtained an Associate degree or transferred, compared to $47.5 \%$ of non-Latino immigrants (Leinbach \& Bailey, 2006).

Yet there is evidence that community colleges are far from reaching their potential as a stepping-stone to 4-year institutions for underrepresented groups, including immigrant students (Chavez, 2008). In California for example, only a small percentage of students who enter community colleges either complete their Associate's degree or transfer to a 4-year institution (Kibler, Bunch, \& Endris, 2011). According to Sengupta and Jepsen (2006), Latino students enroll in disproportionally large numbers in developmental English and ESL courses in community colleges, yet persistence rates from these courses into college-level, credit English courses are low (Bailey, Jeong, \& Cho, 2010). In addition, there are some costs associated with enrolling in community colleges instead of 4-year institutions, such as taking longer to graduate or not transferring to a 4-year institution (Ornelas, 2002). And unfortunately, 
even those students that remain in community college do not necessarily complete an Associate's degree. Of all Associate's degrees earned in 2001, only 10\% were earned by Latinos while $72 \%$ were earned by White males (Murillo et al., 2009).

Given the high number of immigrants, especially Hispanic immigrants who begin their college experience at the community college level, and the important role of community colleges in serving the immigrant population, surprisingly little research exists on this student population within community colleges. This is due, in part, to the scarcity of available institutional and national data on these students' educational experiences (Kim \& Diaz, 2013). Community colleges have been a fundamental resource to respond to diverse needs and create opportunities for students in the communities they serve. However, many factors may encumber immigrant students' success in higher education, even within the community college system (Kim \& Diaz, 2013). For instance, Sutherland (2011) examined the experiences of seven Black immigrant men in a community college and found that family, peers, and community strongly influenced these students' academic achievement. Moreover, once these students transferred to four-year institutions, they faced academic or social difficulties because of an incongruity between what they expected from their institution and what their institution expected of them.

Additionally, only a few studies have examined the postsecondary experiences of Hispanic immigrant students in community colleges. As such, it is imperative to conduct more research to learn about the educational experiences of these students at the community college level. More specifically, we need to know more about the supports and challenges these students experience during their pursuit of an 
Associate's degree, as well as how their second language abilities influence their community college experiences. We also need to know why students stop at the Associate's degree and do not continue through to the baccalaureate degree, as well as the type of advice Hispanic immigrant-ELLs have for other immigrant-ELLs to help them succeed in community colleges. As a new administration within the federal government seeks to shift our nation's priorities, this information becomes critical to consider when thinking about improving the educational opportunities and attainment of Hispanic immigrant-ELLs.

\section{Supports and Challenges in College}

To understand the persistence and degree completion of immigrant-ELLs in community colleges, it is important to recognize that there are several supports and challenges these students may experience while working towards their degree. Several scholars have argued that high quality student-faculty interactions, for example, hold the potential to positively impact college student persistence and achievement (Pascarella, \& Terenzini, 2005; Stebleton, Soria, Aleixo, \& Huesman, 2012). Evidence suggests that informal student-faculty interactions, working on projects with faculty members, or serving on committees with faculty are positively correlated with student learning and development (Kuh, 2003; Kuh \& Hu, 2001).

According to Brilliant (2000), immigrant students report that they value faculty support. However, institutions of higher education offer limited support to immigrant students in the form of one-on-one faculty attention, financial assistance, counseling services, and language learning courses (Kim \& Díaz, 2013). But due to immigrant students' cultural and linguistic differences, this presents a particular problem to 
community colleges looking to successfully meet the needs of these students (Kim \& Díaz, 2013). Immigrant students may present with differences in learning styles, participation rates in classes, and differences in the ways they expect to interact with faculty and peers. Therefore, awareness of cultural differences that affect immigrant students can help faculty and counselors focus on the specific needs of this population (Kim \& Díaz, 2013).

Researchers have also identified academic counseling and advising as important links between students, curricula, and colleges (Orozco, Alvarez, \& Gutkin, 2010). For example, DiMaria (2005) argued that academic counseling and advising as well as high quality online courses, internships, and applied learning can contribute to the academic persistence and success of students who attend community colleges. Orozco et al. (2010) conducted in-depth interviews with 363 students across nine campuses to explore the experiences of Latino, African American, Asian, Native American, White, and immigrant students in the California community college system. Results showed that students thought it was important to find academic counselors who understood their cultural background and could relate to their life experiences. Results also showed that immigrant students felt forced to learn how to navigate a new educational system with limited English-language skills. These students may also feel reluctant to go to academic counselors and advisors because they do not know English well enough to have conversations with them. In fact, several immigrant students communicated that they did not trust their counselors and were not able to relate to them in any way (Orozco et al., 2010). Only a small number of students expressed 
having a long-term or more established relationship with their counselors (Orozco et al., 2010).

Other researchers investigating the academic performance of Hispanic ELLs have utilized a resiliency-based approach to look at ways these students achieve educational resiliency. For example, Reynoso (2008) used a resiliency-based approach to study Dominican ELLs who had achieved academic success despite experiencing personal and socio-cultural barriers. Results from this qualitative study showed that Dominican ELLs relied on a set of successful coping behaviors to overcome the obstacles they faced at their community college. Participants reported that faculty support, tutoring support, counseling support, peer support, family support, selfmotivation, and bicultural identity development fostered their educational resilience and academic achievement. Results from this study highlight the importance of providing adequate college resources and maintaining strong family relationships to help increase the academic resiliency of Hispanic ELLs.

Although some immigrants have successfully navigated and completed their studies at community colleges, there is still a large number that fail to complete their degrees (Conway, 2009, 2010; Rivas, Perez, Alvarez, \& Solórzano, 2007). Due to the open-access nature of community colleges, many students enroll despite their poor preparation to succeed academically. As a result, a large number of community college students perform poorly in their courses or are placed into remedial classes, sometimes causing the students to give up or withdraw (Crisp \& Mina, 2012). In addition, community colleges often lack the necessary resources to ensure that students undergo a smooth transition, receive proper guidance and counseling, and 
obtain the necessary academic support (Crisp \& Mina, 2012). Research has shown that if students do not feel a strong institutional connection they may feel compelled to drop out when they encounter challenges throughout their community college experience (Crisp \& Mina, 2012). In addition, many immigrants who attend community colleges are generally working to pay for their college expenses and as a result, face demanding and often competing work and academic challenges (Sutherland, 2011).

Since community colleges are often the first entry into higher education for Hispanic and low-income students, researchers have looked at the barriers Hispanic students experience at community colleges. For example, Garcia (2010) investigated barriers that first-semester Hispanic students at one community college experienced. The findings suggest a number of barriers. For example, students who were first in their family to attend a postsecondary institution had minimal to no knowledge about timelines and deadlines for filing financial aid. Students also had difficulties registering for classes and received limited information from staff at their community college about ways to navigate the bureaucracy of the college system. Additionally, Alexander, Garcia, Gonzalez, and O’Brien (2007) found that some of the barriers experienced by Hispanic students in community college include the lack of familiarity with knowledge of higher education, inadequate preparation for college, limited or no English-language competence, and a lack of clarity and relevance of higher education. All these factors diminish the likelihood of Hispanic students' academic success.

Thus far, little is known about graduates of International High Schools who go on to college. In a departure from the norm, Murillo (2015) examined the educational 
experiences of Hispanic immigrant-ELLs who are graduates of International High Schools and who completed a bachelor's degree. Results showed that participants felt supported and encouraged by professors and academic advisors and felt connected to at least one professor while in college. They also reported that their professors and academic advisors encouraged them, offered homework assistance, and engaged them in added educational opportunities to help them succeed in college. Yet, the participants faced numerous barriers/challenges in college such as academic challenges and difficulties managing their work and personal life. Participants also felt that their academic work, language abilities, and time management were things that most hindered them during their college years. To date, little is known about the community college experiences of International High School graduates. The aim of the present study was to extend the limited research on immigrant students and ELLs by providing valuable information regarding their community college readiness and community college experiences.

\section{Purpose of the Study}

The purpose of the present study was to explore the high school and community college experiences of International High School graduates who identify as Hispanic immigrant-ELLs. More specifically, the study explored the International High School experiences that seem to foster community college readiness, the supports and challenges experienced by these individuals, as well as the implications of their second language abilities during their time at their community college. In addition, this study looked at the reason(s) many Hispanic immigrant-ELLs may stop at the Associate's degree and do not continue through to the baccalaureate degree, as 
well as the type of advice International High School graduates have for other immigrant-ELLs to help them succeed in community colleges. The current study utilized semi-structured interviews to examine the educational experiences of Hispanic immigrant-ELLs who are graduates of the International High Schools.

\section{Research Questions}

The present study was designed to answer the following research questions:

1) What were the educational experiences of Hispanic immigrant-ELLs during their time at the International High Schools that contributed to college readiness?

2) What were the educational experiences of Hispanic immigrant-ELLs while at their community college?

a) What were the perceived supports and challenges experienced by Hispanic immigrant-ELLs during their time at their community college?

b) What implications did second language abilities have for Hispanic immigrant-ELLs during their time at their community college?

3) Why Hispanic immigrant-ELLs may stop at the Associate's degree and not continue through to a baccalaureate degree?

4) What advice International High School graduates had for other immigrantELLs to help them succeed in community colleges? 


\section{CHAPTER 3}

\section{METHODOLOGY}

\section{Participants}

Twelve International High School graduates who attended a community college and completed an Associate's degree participated in semi-structured, audiorecorded telephone interviews. The sample included women $(n=10,83.3 \%)$ and men $(n=2,16.6 \%)$. Participants ranged in age from 19 to $33(M=25, S D=4.3)$ and all identified as Hispanic/Latino/a $(n=12,100 \%)$. They reported to be originally from the Dominican Republic $(n=4,33.3 \%)$, Colombia $(n=3,25 \%)$, El Salvador $(n=2$, $16.6 \%)$, Ecuador $(n=1,8.3 \%)$, Venezuela $(n=1,8.3 \%)$, and Mexico $(n=1,8.3 \%)$. All of the participants $(n=12,100 \%)$ reported Spanish as their native language.

Table 1 provides a breakdown of the number of years the participants have lived in the U.S. (prior to the study), as well as their age of arrival in the U.S. Length of time in the U.S. ranged from 7 to 20 years $(M=13.0, S D=4.2)$ and all of the participants arrived between ages 6 and $15(M=12.0, S D=4.0)$.

Table 1

Background Information of International High School Graduates

\begin{tabular}{lcc} 
Length of Residence in the U.S. & $n$ & $\%$ \\
\hline Number of Years & & $8.33 \%$ \\
7 & 1 & $16.6 \%$ \\
8 & 2 & $16.6 \%$
\end{tabular}


13

14

15

16

20
$8.33 \%$

$16.6 \%$

$16.6 \%$

$8.33 \%$

$8.33 \%$

Age at Arrival to the U.S.

6

13

14

15
1

3

4

4

$25.0 \%$

$33.3 \%$

$33.3 \%$

Note: $\mathrm{N}=12$.

\section{Measures}

Participants responded to two sets of questions including demographic and personal background questions, and interview questions. Below is a description of each measure used.

Demographic and personal background questions. The participants responded to a set of demographic and personal background questions (see Appendix A). Specifically, participants reported their gender, age, race/ethnicity, native language, reason for immigrating to the U.S., period of time lived in the U.S., International High School attended, year of graduation from high school, community college attended, year of graduation from community college, and number of years it took to complete the Associate's degree. They also indicated their current occupation, 
formal education in home country, interruptions in education, and whether or not they pursued a bachelor's degree or advanced degree since attending a community college.

Interview guide. A semi-structured interview guide containing 10 questions and follow-up probes was created to complete the goals of the study (see Appendix B). The semi-structured interview format was chosen because it allows for openness and flexibility throughout the interview process (Kvale, 1996). This means that the interviewer is able to ask follow-up questions even though pre-determined questions are prepared prior to the interview. Semi-structured interviews give the researcher flexibility in the sequence and form of the questions asked during the interview (Kvale, 1996). Interviews were considered appropriate for the present study because they provide an opportunity to examine individual experiences as well as the meaning participants give to those experiences (Seidman, 2006).

Questions in the interview guide addressed participants' educational experiences during their time at the International High Schools that contributed to their community college readiness. In addition, they asked about participants' educational experiences during their time at their community college. Specifically, participants were asked about the supports and challenges experienced during their time at their community college, implications of their second language abilities, and reason(s) Hispanic immigrant-ELLs may stop at the Associate's degree and not continue through to the baccalaureate degree. In addition, participants were asked to provide advice to other immigrant-ELLs to help them succeed in community college. Participants were also asked at the end of the interview whether they had additional 
information to share that would allow for a more complete understanding of their experiences.

\section{Procedure}

Prior to study implementation, the University of Rhode Island Institutional Review Board reviewed and approved the methods and procedures of the study. After receiving approval for the study, potential participants were contacted and sent a cover letter (see Appendix C) as well as a consent form (see Appendix D) that detailed the study goals, and the risks and benefits related to the participation in the study. The consent form also included information about how participants' confidentiality would be preserved, as well as information relevant to the use of telephone interviews and audiotapes. To participate in the study, participants needed to have completed all four years in high school and graduated from one of the International High Schools between the years 2001-2013, completed an Associate's degree in the U.S., and identify as Hispanic/Latino.

Participants were recruited using a combination of snowball methods and targeted sampling. Facebook groups, emails, and the Internationals Network organization were used to recruit participants. Additionally, a recruitment letter was sent to the principals and teachers of the International High Schools asking them to reach out to their alumni network for their possible participation in the study (see Appendix C). Participants were asked in the cover letter whether they are a former International High School student who completed all four years at an International High School and graduated between the years 2001-2013, completed an Associate's degree in the U.S., and identify as Hispanic/Latino. A total of 16 participants 
responded, but upon questioning, four did not meet the requirements for participation. Those participants meeting the participation criteria $(n=12)$ were asked to sign and return the consent form.

Once participants returned the signed consent form, emails, Facebook messages, text messages, and phone calls were used to schedule interviews. The interviews were scheduled at times that were mutually agreeable for the interviewer and interviewee. The phone interviews lasted approximately 30-45 minutes. At the end of the interview, the interviewer provided a summary of the conversation and sought clarification when necessary (member checking). After the completion of the interviews, each participant was sent a \$20 gift card as compensation for their participation.

The phone interviews were audio-recorded, and the recordings were transcribed verbatim by research assistants who were trained by the primary researcher. Each audio-recording and transcript was reviewed multiple times by the author to ensure accuracy. The transcribing process provided the researcher with the opportunity to develop a deeper familiarity and understanding of the information obtained from the interviews (Braun \& Clarke, 2006). Identifying information was removed from the transcripts and pseudonyms were used to ensure anonymity and maintain the confidentiality of the interviewees.

\section{Data Analysis}

The data was analyzed both quantitatively and qualitatively. Quantitative analyses were performed to analyze the demographic data, while the interview data employed a qualitative descriptive content analysis approach. The goal of qualitative 
description research is to provide a comprehensive summary of events, and to acquire direct answers to unexplored questions (Sandelowski, 2000). Content analysis was used to analyze the data obtained from participants' interviews. Researchers describe content analysis as a flexible method to analyze text data (Cavanagh, 1997; Graneheim \& Lundman, 2003). Content analysis is a technique that examines the subject and the context, as well as the similarities and differences in qualitative data (Graneheim \& Lundman, 2004).

To begin the analysis, each interview was listened to and read several times to obtain a general impression. Then, text that represented the initial research questions were identified. Two researchers independently read the interviews to develop the initial codes that were used to divide the data into meaningful analytical units. These codes came directly from the text and served as the initial coding scheme. The coders then met to compare and discuss categories that included smaller codes and were represented across multiple interviews. After discussion, coders agreed on all categories and subsequently applied them independently to the interview transcripts. Coding results were then compared, discussed, and revised until 100\% agreement was reached. This process continued until the data in all of the interviews had been coded. The researchers also made notes of the similarities and differences across interviews. Analysis of the interviews ceased upon reaching data saturation or a point where the acquired information became redundant (Lincoln \& Guba, 1985). The findings of the interviews are presented using descriptions of International High School graduates' experiences. Quotations are used to support the conclusions made by the researcher (White \& Marsh, 2006). The researcher also kept a detailed account of the entire 
research process by creating an "audit trail” describing what was planned and executed in the study.

\section{Trustworthiness}

Trustworthiness is a critical and important part of conducting qualitative research. Trustworthiness can be achieved by establishing credibility, transferability, dependability, and confirmability of the research (Lincoln \& Guba, 1985). More specifically, "credibility" refers to how well the data and analysis address the intended focus, "transferability" refers to the applicability of the findings, "dependability" to the consistency of the findings, and "confirmability" to the neutrality of the findings (Lincoln \& Guba, 1985). These terms are often compared to validity, reliability, and objectivity in quantitative research (Lincoln \& Guba, 1985).

In the present study, the researcher ensured trustworthiness in a variety of ways. First, the researcher engaged in informal member checking with interviewees by clarifying information obtained to ensure appropriate understanding of the responses. At the end of each interview, the interviewer also provided a summary of the conversation in order to ensure accuracy in participants' experiences. This process helped to establish credibility of the findings and interpretations during the interviews. Moreover, investigator triangulation, in which two coders analyze and interpret the data, was also used to reduce the possibility of bias (Lincoln \& Guba, 1985).

In addition, dependability and confirmability were addressed by using an "audit trail." This allowed for the process and product of the investigation to be documented and examined by an auditor (Lincoln \& Guba, 1985). Trustworthiness 
was also established by providing direct quotations from the interviews and maintaining communication with a consultant who is an expert in qualitative research.

I have a personal commitment to improve the educational experiences of immigrant-ELLs. Growing up as an ELL student myself, and experiencing the challenges of navigating high school and college with limited English proficiency gives me the motivation to help create better educational opportunities for immigrantELL students at the secondary and postsecondary level. My goal is to bring attention to the challenges and supports immigrant-ELLs experience in both high school and community colleges in order to help create more supportive and welcoming environments for them. 


\section{CHAPTER 4}

\section{RESULTS}

\section{Demographic and Contextual Data}

Participants provided demographic and personal background information concerning (a) number of years of formal education in their home country, (b) whether or not they faced interruption in their education, (c) their reason(s) for immigrating to the U.S., (d) the International High School attended, (e) their year of graduation from high school, (f) whether or not they were first generation college students, (g) the community college(s) attended, (h) the number of years they took to complete their Associate's degree, (i) their year of graduation from community college, (j) their reason(s) for deciding to attend a community college, $(\mathrm{k})$ whether or not they pursued a bachelor's degree or an advanced degree, (1) whether they graduated with a bachelor's degree or an advanced degree, and (m) their current occupation.

As seen in Table 2, there was high variability in the number of years of formal education participants received in their home countries, and less variability in their responses to whether or not they faced interruption in their formal education. The one participant who had one year of interruption in his formal education reported that the interruption occurred while he was transitioning to the U.S.

\section{Table 2}

Participants' Formal Education in Home Country and Interruption in Education

\begin{tabular}{ccc}
\hline Years of Formal Education & $n$ & $\%$ \\
\hline 2 & 1 & $8.33 \%$ \\
7 & 2 & $16.6 \%$
\end{tabular}


Interruption in Formal Education

No interruption

One year of interruption
11

1
$91.6 \%$

$8.33 \%$

Note: $\mathrm{N}=12$.

Table 3 provides a breakdown of the reason(s) participants immigrated to the U.S, the International High School attended, and the year they graduated from the International High School. Of note is that participants provided several reasons for immigrating to the U.S., and high variability was seen in the year they graduated from an International High School. Eight out of 12 participants attended Brooklyn International High School.

Table 3

Personal Background Information of International High School Graduates

Reason(s) for Immigrating to the U.S. $\quad n \quad \%$

Father lived in the U.S.

Brought over by family

Desire for economic stability

Family lived in the U.S.

Mother lived in the U.S.

Had to leave home country

3

3

2

2

1

1

$25 \%$

$25 \%$

$16.6 \%$

$16.6 \%$

$8.33 \%$

$8.33 \%$ 


\begin{tabular}{lll}
\hline International High School Attended & & \\
Brooklyn International High School & 8 & $66.6 \%$ \\
Ellis Preparatory Academy & 2 & $16.6 \%$ \\
International High School at Lafayette & 1 & $8.33 \%$ \\
Bronx International High School & 1 & $8.33 \%$ \\
\hline Year of High School Graduation & \\
2003 & 3 & $25 \%$ \\
2004 & 1 & $8.33 \%$ \\
2005 & 1 & $8.33 \%$ \\
2006 & 1 & $8.33 \%$ \\
2007 & 1 & $8.33 \%$ \\
2009 & 2 & $16.6 \%$ \\
2011 & 1 & $8.33 \%$ \\
2013 & 2 & $16.6 \%$ \\
\hline
\end{tabular}

Note: $\mathrm{N}=12$; All high schools are located in New York.

Table 4 illustrates a breakdown of the community colleges attended, number of years participants took to complete their Associate's degree, and the year participants graduated from their community college. Most participants ( $n=10,83.3 \%)$ were first generation college graduates. In looking at the community colleges attended, participants attended and graduated from four different community colleges: Kingsborough Community College, La Guardia Community College, Borough of Manhattan Community College, and Community College of Rhode Island. Of note is 
that five participants took two years to complete their Associate's degree, while the rest took more than two years.

Table 4

Community College Information of International High School Graduates

\begin{tabular}{|c|c|c|}
\hline College(s) Attended & $n$ & $\%$ \\
\hline Kingsborough Community College & 5 & $41.6 \%$ \\
\hline La Guardia Community College & 3 & $25 \%$ \\
\hline Borough of Manhattan Community College & 3 & $25 \%$ \\
\hline Community College of Rhode Island & 1 & $8.33 \%$ \\
\hline \multicolumn{3}{|l|}{ Years to Complete Associate's Degree } \\
\hline 2 & 5 & $41.6 \%$ \\
\hline 2.5 & 3 & $25 \%$ \\
\hline 3 & 1 & $8.33 \%$ \\
\hline 3.5 & 2 & $16.6 \%$ \\
\hline 4 & 1 & $8.33 \%$ \\
\hline \multicolumn{3}{|l|}{ Year of College Graduation } \\
\hline 2005 & 1 & $8.33 \%$ \\
\hline 2007 & 1 & $8.33 \%$ \\
\hline 2008 & 2 & $16.6 \%$ \\
\hline 2012 & 3 & $25 \%$ \\
\hline 2013 & 3 & $25 \%$ \\
\hline 2016 & 2 & $16.6 \%$ \\
\hline
\end{tabular}

Note: $\mathrm{N}=12$; Three community colleges are located in New York and one in Rhode Island. 
Participants also reported the reason(s) they decided to attend a community college, and high variability was seen in their responses (see Table 5). A number of participants reported that they did so because they were not able to afford a different institution (e.g., a four-year college), while others reported that they decided to attend a community college because it was accessible to them/close to home, they had low grades in high school, or because the community college they chose offered their intended field of study.

Table 5

Reason(s) Participants Attended a Community College

\begin{tabular}{llc}
\hline Reason & $n$ & $\%$ \\
\hline Accessible/close to home/work & 4 & $33.3 \%$ \\
Couldn't afford a different institution & 4 & $33.3 \%$ \\
Low grades in high school & 2 & $16.6 \%$ \\
Recommended by a teacher & 1 & $8.33 \%$ \\
$\begin{array}{l}\text { Had a language barrier } \\
\text { Offered intended field of study }\end{array}$ & 1 & $8.33 \%$ \\
$\begin{array}{l}\text { Helpful way to begin college education } \\
\text { Transcripts were not sent in time to other } \\
\quad \text { institutions }\end{array}$ & 1 & $8.33 \%$ \\
$\begin{array}{l}\text { Community colleges provide flexibility for } \\
\text { students who have jobs }\end{array}$ & 1 & $8.33 \%$ \\
$\begin{array}{l}\text { Wanted to pursue higher education } \\
\text { nate: }\end{array}$ & 1 & $8.33 \%$ \\
\end{tabular}

Note: Total does not equal $12(100 \%)$ because some participants provided multiple responses. 
Additionally, participants reported whether or not they have pursued a Bachelor's degree or an advanced degree. The majority of participants $(n=10,83.3 \%)$ reported that they have pursued a Bachelor's degree. However, out of them, four $(40 \%)$ graduated with a Bachelor's degree. The remaining six $(60 \%)$ communicated that they are still working towards the completion of their Bachelor's degree. Two participants (16.6\%) reported that they have not pursued a Bachelor's degree or an advanced degree, but one $(8.33 \%)$ indicated that she is planning on doing so.

Participants also shared information about their current occupation. A close examination of this information shows that the majority hold occupations that require a particular knowledge or skill to perform their specific role. Table 6 provides a list of this information.

Table 6

Participants' Current Occupation

\begin{tabular}{lcc}
\hline Occupation & $n$ & $\%$ \\
\hline Student & 2 & $16.6 \%$ \\
Media/film maker & 1 & $8.33 \%$ \\
Teacher assistant & 1 & $8.33 \%$ \\
Counselor & 1 & $8.33 \%$ \\
Hospital care investigator & 1 & $8.33 \%$ \\
Graphic designer & 1 & $8.33 \%$ \\
Recreational therapist & 1 & $8.33 \%$ \\
Documentation exporter & 1 & $8.33 \%$ \\
Accountant & 1 & $8.33 \%$ \\
\hline
\end{tabular}


Assistant recreational leader

Office worker for dry-cleaning service
1

$8.33 \%$

1

Note: $\mathrm{N}=12$.

\section{Research Questions}

The results of the interviews are organized with respect to the four research questions. For each research question, descriptive tables are provided to summarize the categories or explicit messages elicited from the participants. The findings are also presented through a narrative and quotations are used to support the conclusions and interpretations made by the researcher (White \& Marsh, 2006).

Research question 1: What are the educational experiences of Hispanic immigrantELLs during their time at the International High Schools that contribute to college readiness?

The first research question examined ways in which the International High Schools prepared participants for college. Participants answered three main questions and three follow up questions to address this research question. The first question asked participants to describe in detail their life at the International High School. Their answers fell into five categories as depicted in Table 7.

Table 7

Experiences at the International High Schools

Categories $n(\%)$

Helpful and supportive individuals

$10(83.3 \%)$

Generally good experience

$8(66.6 \%)$

Miscellaneous (e.g., took school $5(41.6 \%)$ seriously due to familial 
expectations, resources needed to advance to college, many different cultures, first year was very shocking)

Faced with language barrier $4(33.3 \%)$

Personal motivation to learn English $2(16.6 \%)$

Note: Total does not equal $12(100 \%)$ because some participants provided multiple responses.

Helpful and supportive individuals. The majority of participants indicated that during their time at the International High School they received help and support from many people including teachers and classmates. One participant spoke directly about this by stating:

The teachers there were very helpful, they were very understanding, willing to help me out... It was hard for me to understand English at the time, but they didn't take that into account to fail me or anything. They did their best to help me pass my classes and get good grades, and stay there in school and not drop out of high school.

Generally good experience. Many International High School graduates indicated that being at an International High School was a good experience for them. One reported that "it was great to have had the opportunity to go to an international high school," while another communicated that the International High School "felt like "family" and were "very supportive." One participant spoke directly about the help she received to learn the English language:

I think I got more help there especially with the language because I didn't speak anything in English at that time. 
Miscellaneous. Participants also shared a variety of other experiences when they were asked about their life at the International High School. For example, one participant talked about taking high school very seriously due to familial expectations:

When I started high school I took it very seriously because my family was always about doing well in school, so on my second day I remember I came back with homework and it was meant to be a group project that was supposed to take us one month. And when I took it to my teacher she was like 'you weren't supposed to finish this, you were supposed to do it in a group and it was supposed to take one month.' So after that I had to like tone it down a little bit.

Another participant spoke about her negative experience during her first year at the International High School:

The first year was very shocking for me. I didn't like it and I wanted to go back. Yeah it was a very bad experience. I just concentrated on learning the language and I did that by studying independently.

Faced with language barrier. Some participants reported that they felt language was a barrier because they did not speak English well and had a difficult time trying to understand their teachers and peers. For example, one participant reported:

At first it was really hard because I didn't understand what the teachers were saying and everything was in English so I didn't know anything about what they were saying.

Another stated:

It was actually scary because of the language barrier mainly... It was hard for me to understand sometimes what the teachers were teaching, but that's where I actually learned the language.

Personal motivation to learn English. Two participants reported that they had a personal motivation to learn English while at the International High School. For example, one participant reported: 
After $10^{\text {th }}$ grade the teacher took me as an example because of how much \{English\} I had learned. They were asking me how I did it, and I just told them like it was more me actually going and taking the next step and doing it myself and not just you know, go from $8 \mathrm{am}$ to $3 \mathrm{pm}$ and learn whatever the teachers were teaching, and not go home and do nothing.

The second question asked participants about ways in which the International High Schools prepared them for college. Table 8 represents the three categories that emerged from participants' responses.

Table 8

College Preparation by International High Schools

Categories $n(\%)$

\begin{tabular}{l}
\hline $\begin{array}{l}\text { Academic and language learning } \\
\text { activities }\end{array}$ \\
\hline$(75 \%)$
\end{tabular}

Opportunity to take college courses $\quad 5(41.6 \%)$

Internship opportunities $\quad 4(33.3 \%)$

Note: Total does not equal $12(100 \%)$ because some participants provided multiple responses.

Academic and language learning activities. Most International High School graduates communicated that the International High Schools prepared them for college through academic and language learning related activities. These activities included writing assignments, projects, and portfolios. One participant reported that they were “doing portfolios, presentations, using powerpoints, doing research papers" to be better prepared for college. Another stressed the importance of portfolios by stating:

One was the portfolios. I think the portfolios really helped us become more independent in the sense where you had to come up with a presentation and deliver it to other people. It made us engage in research and stuff like that, so I'd say that portfolios were the strongest part that really helped prepare me for college. 
Opportunity to take college courses. Several participants reported that the International High Schools provided them with the opportunity to take college level courses after school. One participant noted the following:

I think what helped me the most was enrolling in College Now. I heard from the college advisor or the social worker, she introduced the program to a student and then that student told me about it. So I went to her and told her I wanted to enroll as well, then she gave me the application and I got in contact with Elizabeth and I started taking one and two college classes while I was in high school in my senior year. So after I was done with school, I would go to college and take college classes. So that was a program that they offered me and I think it helped me a lot.

Internship opportunities. Participants also had the opportunity to explore possible career choices by participating in internships while at the International High Schools. For example, one participant reported: "I used to do internships related to the things I wanted to do, so I got involved in a lot of things thanks to my advisor and teachers." Another participant described in detail his internship experience and how it prepared him for college:

Well we did internships about like the career that we wanted to like seek further on. I wanted to be a speech pathologist at the time so I ended up interning at NYU Hospital. I had more than one mentor which was great, which I ended up having like recognition for doing a good job during my internship. So I would say that that really shaped me to achieve my goal and not think about all the things I had to do before I actually went to college. More like this is my goal and this is how I'm going to do it. So I will say they did prepare me pretty well for college.

In order to obtain more information about participants' college preparation, they were probed with three further questions. The first follow up question asked, "What messages did you receive at the International High School about going into higher education?" Table 9 represents the four categories that emerged. 
Table 9

Messages Received at the International High Schools about College

\begin{tabular}{lc}
\hline Categories & $n(\%)$ \\
\hline Encouraging and positive messages & $11(91.6 \%)$ \\
$\begin{array}{l}\text { Personal preparation for } \\
\text { college }\end{array}$ & $6(50 \%)$ \\
$\begin{array}{l}\text { Miscellaneous (e.g., Didn't get any } \\
\text { help, different from high school, } \\
\quad \text { language obstacle) }\end{array}$ & $3(25 \%)$ \\
$\begin{array}{l}\text { Messages and support from } \\
\quad \text { organizations }\end{array}$ & $2(16.6 \%)$
\end{tabular}

Note: Total does not equal $12(100 \%)$ because some participants reported more than one response category.

Encouraging and positive messages. Participants whose responses fell into this category reported that they received positive and encouraging messages from a number of individuals at the International High Schools about going to college. One participant noted:

The message was to go to college. But for someone like me, who is first generation going to college they showed me, you know, if I was going to college, all that I would become.... They were always encouraging you as a student to continue educating yourself because the more you were educated, the more opportunities you have in this country.

Another participant mentioned that teachers and staff at the International High Schools encouraged students to keep working hard and complete all the work that is required of them:

Well they used to tell me if I did a good job in high school, if I try to learn as much as possible, it will be not that difficult for me in college... They just told me if you do your work here, do also all the work that you have to do in college, it's going to be a lot easier. They told me for example, read all kinds 
of books so you improve your reading, speak with your friends in English so you learn more things, because these are the things that are gonna help you in college.

Personal preparation for college. Graduates of the International High

Schools received messages about how to personally prepare for college. This entailed how to apply for college, explore different career options, and how to seek help. One participant discusses this point:

I remember we had different workshops and the counselor was actively telling us like how to fill out an application for college. They gave us like the different options we had.

Another participant shared a similar experience:

So they started talking about different colleges, different careers, how to go about it. The steps that we needed to take to get there.

Miscellaneous. Other participants shared a variety of messages received at the International High Schools about going to college, such as ways in which high school is different from college, the obstacles they may experience in college, and how certain students received more help than others with regards to their college applications. For example, one participant reported that his teachers told him about the challenges he may experience in college compared to native-born counterparts:

Of course as an international student they used to tell me, well some teachers were honest with me, and would tell me that 'there are lots and lots of students that were born here like Native Americans, like with the language, they don't have these obstacles with the language, so of course they have different education than you and it's probably gonna be a challenge for you somehow, and this is why you have to prepare now and learn everything you have to learn.'

Messages and support from organizations. Two participants reported that they received messages and support from organizations that worked with the International High Schools. Here is one account: "Well we had a program, it was 
called iMentor. We had a mentor that really encouraged us to go to college." Another participant described the support she received from one of the outside organizations at her International High School:

What I did was go to a program called Fifths, they are in another location, but they came to my high school.... They helped me out and paid the application fees for the colleges and helped me out with my essays. So I think I got the information with that organization. They were the ones who helped me with the application and showed me some colleges, took me to some colleges upstate that I really liked.

The second probe asked participants, "Do you think the International High School provided you with the necessary skills to complete your Associate's degree, and why?" Specifically, participants' responses fell into four distinct categories (see Table 10).

Table 10

Skills Acquired that Contributed to College Completion

Categories n(\%)

\begin{tabular}{lc}
\hline $\begin{array}{l}\text { Provided academic/language } \\
\text { preparation }\end{array}$ & $8(66.6 \%)$ \\
$\begin{array}{l}\text { Provided support and encouragement } \\
\text { to complete degree }\end{array}$ & $7(58.3 \%)$ \\
& \\
Miscellaneous (e.g., small & $6(50 \%)$ \\
school/classes, diversity in \\
schools, concentrate more, being \\
$\quad$ alone in college/independent, \\
$\quad$ going to an international school \\
$\quad$ opens opportunities) \\
$\begin{array}{l}\text { Gained minimal knowledge/not fully } \\
\text { prepared }\end{array}$
\end{tabular}

Note: Total does not equal $12(100 \%)$ because some participants provided multiple responses. 
Provided academic/language preparation. Many International High School graduates felt that the International High School prepared them for college and provided them with the academic and language preparation needed to complete their Associate's degree. Here is an example:

I actually learned a lot. When I went to get my associate's it wasn't hard at all even though I only had four or five years in the country, I felt good. I felt good with the classes and I was actually in advanced classes for three of four semesters. I felt that the material was actually-I was advanced with the material that I had at the community college. I guess it prepared me well.

Another International High School graduate described a variety of academic activities the International High School provided that helped him complete his Associate's degree:

I guess learning at an International School, a lot of students don't know the language so they try to encourage them by writing a lot of essays and writing portfolios, doing presentations, doing readings, preparing us for that.

Provided support and encouragement to complete degree. Participants whose responses fell into this category reported that the International High Schools provided support and encouragement for them to complete their Associate's degree. One participant stated:

I will say based on my experience I had a lot of people supporting me; my teachers were always there, any questions I had. Even the school secretary, if I went to them, they'd be like 'I have so many scholarships you could apply to.' Like they weren't even teachers but they knew I needed scholarships so everybody was on board with every student. They knew our needs and what we really wanted because everybody was so close. I felt like I was really appreciated during my time and I felt like encouraged to graduate and actually feel like I had a chance to go to school even if I couldn't afford it.

Another participant shared a similar experience:

I think they did, actually. I remember one of my teachers telling me, 'right now in high school I'm holding your hand for everything.' And she used to tell you, 'I'm gonna prepare you because college is not like that, it's not like they don't care, they don't give you as much attention as you get in high school.' 
Miscellaneous. Half of the participants shared a number of other factors that contributed to their college completion. For example, one participant reported that she felt the International High School provided her with the necessary skills to complete her associates degree because the school had small classes and teachers closely monitored students' work:

Well yes. The reason why is because you had to be on top of your work all the time. They were always monitoring you because it was a small school and you were only 18-20 students in a classroom.

Gained minimal knowledge/not fully prepared. Some participants felt that they gained minimal knowledge while at their International High School and/or did not feel fully prepared for community college. One participant felt that there were many things she did not learn in high school and she had to teach herself:

There are a lot of things we didn't know and they didn't teach us in high school. It was hard. There is a lot of stuff that they don't teach you. When I came here they didn't say anything about how the grammar is in English. But I basically had to teach myself.

Another participant communicated:

I think I had more things to do especially in writing because when you come from another country especially me, I used to confuse the writing, you know, how you speak English is not how you write, so that was one thing I had a little trouble with, but on the other side it was good. They should be having a little more support to write more.

The third probe asked participants the question, "Did anyone at the International High School give you any advice about college? If so, what advice did you receive?" Table 11 represents the four categories that emerged. 
Table 11

Advice Received at International High School About College

Categories $n(\%)$

General encouragement/input about attending college

$6(50 \%)$

Miscellaneous (e.g., advice about

$4(33.3 \%)$ careers in college, financial aid, classes are hard, advice about going to a 4-year college vs. community college)

Advice about the $3(25 \%)$ importance/benefits of a college degree

Advice about how to be successful in college

Note: Total does not equal $12(100 \%)$ because some participants provided multiple responses.

General encouragement/input about attending college. Half of the participants shared that they were given general encouragement and input about attending college. One participant spoke directly about the advice she received from her mentor:

My mentor Kia - she was very helpful. She, like I said before, she used to encourage me to not give up and just continue my education. I remember when she used to tell me I was smart and that I could do better, and you know that actually helped, just seeing the positive feedback from my teachers and all the positive comments that actually encouraged me to pursue a higher education and to get my other friends to go into college. That was another thing that actually motivated me to continue my education.

Another participant shared the encouragement she received from one of her International High School teachers: 
Well they were always telling me to follow what I wanted to do. I remember that. One teacher actually told me to go for teaching math because I was always good at math. They always kept pushing me forward.

Miscellaneous. One third of the participants described a variety of advice received at the International High School, such as how to apply for financial aid and the difference between attending a community college versus a four-year college. For example, one participant expressed the following:

Well I got accepted to a four-year school. They \{the International High School\} wanted me to go because they knew it was a better decision than going to a two-year school. But they accepted my decision and said it was better to go to a community college.

Advice about the importance/benefits of a college degree. Other participants reported that they received advice about the importance and benefits of a college degree. One participant recalled the advice she received from her teachers:

Like it was many many times that I wanted to give up and quit school, but they always helped me. They always told me that if I finished college, my life would be a little bit easier.

Another participant shared the advice he received from his science teacher:

My science teacher. She talked about college and how important it was to get a job. Education is one of the most important things if you want to be successful.

Advice on how to be successful in college. Two participants received advice on how to be successful in college, and this included advice on time management, the importance of communicating with professors, and study habits. Here an International High School graduate provides an example of the type of advice she received:

I remember going to one of my teachers and being like 'how am I going to be able to write these essays and do all this work that's thrown at me.' And she was like 'don't worry about it, make sure that once you go to class get to know your professors; let them know and they will work with you. Some professors are easier than others, but don't give up from the first day and actually try to 
communicate with your professors. As long as you try your best at whatever it is, whether it's reading or writing, you will succeed.

Previous research (e.g., Fine et al., 2005) showed that about $90 \%$ of

International High School graduates were accepted to colleges upon their high school graduation, and participants shared their thoughts on why the International High

Schools had this rate. Participants discussed a few reasons why the International High Schools had such a high college acceptance rate and their responses fell into three different categories (see Table 12).

Table 12

Reasons Why the International High Schools had High College Acceptance Rate

Categories $n(\%)$

Parental and teacher influences

$8(66.6 \%)$

Students strive to continue education

$6(50 \%)$ further

Colleges seek diversity $3(25 \%)$

Note: Total does not equal $12(100 \%)$ because some participants provided multiple responses.

Parental and teacher influences. Graduates of the International High Schools felt that they had a high college acceptance rate because the teachers and parents were very influential in their lives and encouraged them to do well in school. One participant described the encouragement she received from her teachers:

I think it's because the amount of encouragement we get from our teachers. It's more like we met-like I don't remember feeling like an outsider, it was more like a cultural barrier, and also the language, but we were never depicted as like immigrants like 'oh this school is for you because you're an immigrant,' you know, it was never like that. It was more of like 'oh we're a family, we're all going through some things that are similar.' Even though we don't speak 
the same language we still struggle with it, we still struggle with the culture and we were like very sheltered by our principal and teachers to not feel like outsiders.

Other participants spoke directly about the impact that parents make in their children's education:

The students, we have different backgrounds, different cultures, and as Latinos, because I'm Latino, as Latinos we push our kids to do the best. And besides the school's help, parents have to do something with it...Yeah and also with the school together. I'm saying this because I'm a parent and I know. I want the best for my kid and I want them to be a professional. And our parents, they always say that to us: 'I want you to grow up, be the best student, I want the best future for yourself and have a career...The main thing for our parents, and also our goal, is to succeed in this country. And to succeed in this country means getting an education. So that pushed us to be better. We have to go to school, we have to graduate, we have to go to college and that's something for our parents and for us.

Students strive to continue education further. A commonly expressed

reason why the International High Schools have high college acceptance rates is

because international students have a personal motivation to continue their education

beyond their high school years. For example, this participant stated:

In my experience, I think it's because they \{students\} have this wish to continue their education, this desire to go to college. And, I guess somehow International High Schools show these kids-kids as me that we have opportunities here even though we came from different backgrounds, we also have a chance to be successful here.

Another participant stated that many International High School students come from lower income backgrounds and this motivates them to pursue their dreams and seek higher education:

And the international students, most of them, they come from very low income families and sometimes they want to do better in life. They don't want to be stuck in the same place so they always strive for the best. They always do their best to achieve their goals and I think that poverty too has a lot to do with that, seeing the opportunities that this country offers to us, to any person that wants to pursue a higher education. 
Colleges seek diversity. International High School graduates spoke of colleges striving to admit students from diverse cultural, ethnic, and racial backgrounds. One participant expressed this idea: "Ethnicity, I guess. They want more people to go to college, from different races.” Another participant further explained that a reason colleges strive to admit international students is because they realize that these students have a strong desire to continue their education:

I guess also more colleges realize there are a lot of international students that have this desire to continue academically, let's say, which is why they start accepting them more and more.

Research question 2: What are the educational experiences of Hispanic immigrantELLs during their time at their community college?

To answer this research question, participants described the ways their high school life differed from their community college life with regards to their educational experiences. Four categories of responses emerged. The majority of participants reported that high school was a more comfortable and supportive environment for them, while the rest reported a variety of ways in which high school was different from college, such as having to balance school and work life while in college, becoming more independent, and encountering more challenging classes. Table 13 provides a breakdown of this information.

Table 13

Ways High School was Different from College

Categories n $n(\%)$

\begin{tabular}{l}
\hline High school was a more \\
comfortable/supportive \\
environment
\end{tabular}


Miscellaneous (e.g., different

$6(50 \%)$ schedules, took college more seriously, time management, college was like high school, unable to establish longer relationships, high school smaller than college)

Became more independent/personally responsible

College was more challenging $4(33.3 \%)$

Note: Total does not equal $12(100 \%)$ because some participants provided multiple responses.

High school was a more comfortable/supportive environment. International High School graduates also communicated that in comparison to college, the International High Schools provided a more comfortable and supportive environment. Here is one account of a participant who felt more comfortable in high school because she knew everybody in the school:

I think well, let me think, in high school I felt more comfortable because I know the people, the same people every day. And in college, there is a lot of people that you don't know and you don't feel like that familiar as in collegeI mean as in high school.

Other participants explained that teachers at the International High School "were always available and were always offering to help," and that "in high school, you have more support, the teachers are more close to you. In college, not so much."

Miscellaneous. Participants also reported several other reasons college was different from high school. For example, one participant stated:

I will say I took college a lot more serious than high school because like I knew if I-like if I did my homework and got an 80 I'd be fine. So like I was 
okay with that; I was never the student to go like above and beyond like I was just okay with a passing grade.

She continues by describing the difficulties she experienced in trying to find a balance between her school and work life:

But then I actually, when I started college, I was like 'oh my God I have to get everything done before the deadline.' So I was always thinking about deadlines and like getting everything on time because I was also like working at the time to pay for school, so it's like juggling between school and work. Like I remember doing homework in my bed like right before I go to sleep like okay, I'm just gonna spend this amount of time and finish it and then I'll be fine. It was more like time management.

Became more independent/personally responsible. Participants stressed that they had to learn how to study independently and become more personally responsible. One participant explained:

Well you become more independent, so of course you have the same responsibility which is doing your work and being there. So like nobody is there to tell you, you have to read this, you have to do this. It's your responsibility to know. And somehow you feel kind of alone there, but you're not.

A second participant shared a similar experience:

Actually I was the one encouraging myself to actually finish the work without having like a group of people who were like constantly telling me I could do these things, you know? So I would say that's the difference.

College was more challenging. One third of the participants reported that college was more challenging because they encountered more challenging classes and it was more difficult to get in contact with professors. For example, one participant described this as:

The classes, because the classes in college are way more advanced. In high school was a little, high school was way easier than college just because college you really really have to focus and get used to the new environment, new, you know, it's no longer teachers; now you have to call them professors and things like that. 
Likewise, another participant compared college to high school by saying:

Also was challenging because you could still talk with your professors and advisor, but it's kind of not the same, because Ellis was a very small high school so you have more contact with your teachers or with any teacher there, so you were more confident with them. But in college it's not only me; there are thousands of students there so you had to limit contact with your professor or your teacher or counselor or advisor.

In order to obtain more information regarding participants' educational experiences at their community college they were probed with the following question: "Can you talk about your English skills in high school and how they compared to what they were when you were in college?" five categories developed from participants' responses (see Table 14). A close examination of their responses show that the majority of participants reported that they struggled with English in and throughout high school, while the remaining spoke about the different academic activities that helped improve their English skills, ways in which their English skills improved over time or progressed in college, and the need to work harder in college.

Table 14

English Skills in High School and Community College

\begin{tabular}{ll}
\hline Categories & $n(\%)$ \\
\hline $\begin{array}{l}\text { Struggled with English in and } \\
\text { throughout high school }\end{array}$ & $10(83.3 \%)$ \\
$\begin{array}{l}\text { Classes/academic activities helped } \\
\text { improve English skills }\end{array}$ & $7(58.3 \%)$ \\
$\begin{array}{l}\text { English skills improved over } \\
\quad \text { time/progressed in college }\end{array}$ & $6(50 \%)$
\end{tabular}


Miscellaneous (e.g., teachers spoke

Spanish in high school, friends

helped learn English; easier in

high school than in college)

Worked harder to learn English in college

$3(25 \%)$

Note: Total does not equal $12(100 \%)$ because some participants reported more than one response category.

Struggled with English in and throughout high school. The majority of participants reported that they struggled speaking, writing, and reading English in and throughout high school. For example, one participant explained the difficulties she experienced writing and speaking English during her time at the International High School.

Ok my English skills back in high school were awful (laughs), it was hard. But like teachers were always there to help. My writing skills were awful. My communication skills were even worse. I never wanted to speak up, it was very embarrassing for me to speak up.

Another participant shared a similar experience and added that public speaking was the most difficult for her: "Well, I think, in high school I had problems writing, speaking - public speaking actually was the worst."

Classes/academic activities helped improve English skills. A number of participants mentioned that classes and academic activities such as writing assignments, workshops, and class readings helped improve their English skills in both high school and college. One participant communicated:

I remember taking some public speaking classes and it was very frightening at first. They actually helped me to open up to be more secure, and not be afraid of sharing my thoughts in college. 
This other participant talked about the benefits of attending English workshops after class:

When I came to college they offered me like, specifically after I was done with my classes, like maybe three or four o'clock, they had English workshops. And so I attended them, and they helped me even more because I had to write way more essays, have papers done in a week, two weeks. So they really really helped me a lot with that.

\section{English skills improved over time/progressed in college. Half of the}

participants reported that they entered the International High School with limited English skills, but that their English skills continued to improve through their years of high school and college. One participant stated: "My English was like level—like I can say from 1-10, I think it was like a 5 in high school, and I improved in college (laughs). Not that much, but I did." Another participant stated that it was easier to communicate in English as time went by because he felt encouraged to communicate with students that came from other parts of the world:

But as I got the hang of it, it was more easy to communicate, you know, with people that came from different parts of the world; Africa and stuff like that, you know. So it was a great experience and it really encouraged me to learn English because as I said you would really like to communicate with them.

Miscellaneous. International High School graduates also reported a number of other responses when asked to talk about their English skills in high school and how they compared to what they were when they were in college. For example, one stated that English was easier in high school than in college because almost all of her high school teachers spoke Spanish:

Well in high school I was actually learning the language. I'm still learning it, but it was a little bit easier because sometimes I could communicate with the teachers. Mostly all of them understand and speak Spanish too, so it was easier. 
Another participant commented that her friends helped her improve her writing skills in college:

Then I actually had a friend who, I had two friends who would proofread my work. Like I remember this one time, one of my friends, she went to a private school, well mostly like all of my friends went to universities so I will always look up to them. So I remember telling them you know what, like how can I write a good essay? Can you actually show me because I'm lost, and I remember she's like, 'okay, this is what they want you to write, it doesn't matter if it's wrong or it's right, it's what they wanna hear from you, so it's what you're gonna write.' So I started doing that and all my essays were right and I remember getting my first A and couldn't believe it because I was so shocked! I remember I was like wait, I'm gonna re-check online because I don't think this is right. So I ended up getting A's on my essays.

Worked harder to learn English in college. Three participants reported that they felt they worked harder in college in order to improve their English skills. Here is one account: “And in college, I pushed myself a little bit more so I can finish my job, and write more. I had to read a lot, way too much." Here is another account: "Then once I got to college I was maybe forced to do it. It wasn't like high school. So I had to push to not be afraid of speaking up due to my language barrier."

Research question 2 (a): What are the perceived supports and challenges experienced by Hispanic immigrant-ELLs during their time at their community college?

This research question examined the different supports and challenges participants experienced while in their community college. They were asked one main question and eight follow up questions. The first question asked participants if they encountered supports that helped them complete their Associate's degree. Four categories developed from participants' responses (see Table 15). A close examination of their responses shows that a majority of participants received support from academic programs/tutoring. Others received support from their faculty/professors, 
family members and peers, while a few reported a variety of other responses (such as support available but they never looked for it).

Table 15

Supports Experienced by Participants While They Were in College

\begin{tabular}{lc}
\hline Categories & $n(\%)$ \\
\hline Support from academic programs & $8(66.6 \%)$ \\
Support from faculty/professors & $7(58.3 \%)$ \\
$\begin{array}{l}\text { Miscellaneous (e.g., supports were } \\
\quad \text { available but didn't take } \\
\text { advantage, encountered other } \\
\text { people in college, study groups) }\end{array}$ & $3(25 \%)$ \\
$\begin{array}{l}\text { Support from family } \\
\text { members/peers }\end{array}$ & $2(16.6 \%)$
\end{tabular}

Note: Total does not equal $12(100 \%)$ because some participants provided multiple responses.

Support from academic programs. International High School graduates reported that they received support from academic programs such as the writing center and outside-of-class tutoring. For example, this participant explained:

The college offered other programs to help students on their writing skills. I remember visiting the writing center and they were very helpful. Especially in finals week when I had to write essays. They were always available for anyone to go there and get the help they needed.

Another talked about the help he received from one of the academic programs he was a part of:

Well I had a program. College Discovery helped me a lot. It's a program, they help you out with tutoring. You have a counselor, you know, and they really help you out during the semester in order for you to be on task. 
Support from faculty/professors. Support from faculty/professors was

frequently identified as critical for participants' community college completion.

Generally, participants identified that faculty and professors provided academic and

financial aid advice, as well as other educational opportunities to help them succeed.

Here one described the advice she received from one of her professors:

I had a professor that I keep in contact with. He was always giving me advice on you know, higher education, just on how to complete my bachelor's degree, how to sign up for different schools, and he was really helpful.

Another described her professor's commitment to help keep her in college after she

found out that the participant did not have the means to pay for college:

Yeah. I had especially one teacher \{professor\} that was always helping me. Yeah one professor, and I still remember too even the financial aid because I had to pay for it. I didn't get no financial aid or anything like that. And one thing I remember, one month I was behind and she told me all you need to do is talk to me, and she said if I have to give you a loan from myself I will give you a loan. Because I was telling her I was going to stop for one semester, take a break to come up with the money. And she actually told me if you need it, I know your potential, I'm willing to do that for you. I didn't take the help because thank God I got the money that I needed, but she was always there for me.

Miscellaneous. Some of the participants provided a variety of other responses to this question, such as not taking advantage of the academic support available at their college, receiving help and encouragement from other individuals they met during their community college years, and support received through study groups. This one participant communicated that even though her community college offered academic support to help students complete their Associate's degree, she decided not to take advantage of that support:

I mean you can look for support there, there's definitely a lot of support. There are counselors and offices where they can help you if you need anything. There are tutors. They have all the kind of resources you need in college, but I 
personally didn't take advantage of it. I just did it myself, went to the classes and did what I had to do.

Support from family members/peers. Two participants reported that they

received support from family members and peers, which contributed to the attainment of their Associate's degree. This particular International High School graduate spoke about the support she received from her father: "My dad. He always pushed me even when he starts seeing that I give up, or that I don't want to do it, he always pushed me." This other participant described the help she received from other classmates:

But then I did find people that I met in school that were even younger than me, and they were like 'okay, you're not wrong, you have to like focus on this,' and that's how I was able to succeed.

In order to obtain more information about the supports participants encountered while in community college, participants were probed with eight further questions. The first follow-up question asked participants, "What are the top two or three things or people that helped keep you in college?" Table 16 presents the four different categories that emerged.

Table 16

Top Things or People that Helped Keep Participants in College

\begin{tabular}{lc}
\hline Categories & $n(\%)$ \\
\hline Family members/friends & $10(83.3 \%)$ \\
Personal motivation to succeed & $5(41.6 \%)$ \\
Faculty/staff/counselors in college & $3(25 \%)$ \\
International High School teachers & $2(16.6 \%)$
\end{tabular}

Note: Total does not equal $12(100 \%)$ because some participants provided multiple responses. 
Family members/friends. The majority of participants communicated that family members/friends provided significant encouragement and support for them to stay in their community college. For example, this participant noted: "The top one is my dad and my daughter." Another participant stated: "Seeing my other friends too going to college. And then my family too."

Personal motivation to succeed. Almost half of the participants also stressed that their own personal motivation and drive to succeed was what helped them stay and graduate from their community college. This was illustrated by the following examples: "Well, first of all I think I was the main reason I succeeded." Another participant discussed how her main goal was to obtain a bachelor's degree and staying and completing her Associate's degree was a stepping-stone to doing that:

I guess the first top was my desire to get a bachelor's degree... Yeah an Associate's degree, but to continue. That was just one step, that was like the first reason like to get into college.

Faculty/staff/counselors in college. Three participants identified college faculty, staff, and academic counselors as valuable support for them to stay and graduate from college. Here is one account: "The other person was my counselor from BMCC in the ASAP program."

International High School teachers. Two participants indicated that teachers and school counselors at their International High School motivated them to continue their college education. Here are their responses:

I will say one of my high school teachers because I still keep in contact with her. Miss Carol, she was my biology teacher.

Yeah a high school counselor, a guidance counselor. And all my teachers, they were good. 
The second follow-up question asked participants to talk about the ways in which their family members, friends, faculty/staff/counselors, their own motivation to succeed, and their International High School helped keep them in college. Three main categories developed from participants' responses: provided support and encouragement, provided motivation/inspiration, and helped them achieve personal goals. Table 17 provides a breakdown of this information.

Table 17

Type of Help Participants Received in College

Categories $n(\%)$

\begin{tabular}{lc}
\hline Support and encouragement & $8(66.6 \%)$ \\
Motivation/inspiration & $8(66.6 \%)$ \\
$\begin{array}{l}\text { Own motivation helped achieve } \\
\text { personal goals }\end{array}$ & $2(16.6 \%)$
\end{tabular}

Note: Total does not equal $12(100 \%)$ because some participants provided multiple responses.

Provided support and encouragement. A number of participants reported that they received support and encouragement and that helped them complete their Associate's degree. For example, one participant spoke directly about the support she received from one of her International High School teachers:

I will always go to her and like tell her, or she will see me doing homework and she will be like 'you're almost there you know, don't give up. Why would you not keep going to school? Like it doesn't matter, like you took all this time and things happen, but so what? Everyone goes at their own time.' So I always remember her being like 'you're fine, you're almost there.' So I will say like she made a big impact. 
This other participant spoke about the support and encouragement she received from her family members:

Seeing some of my other family members going to college to. My dad and my mom telling me not to give up, and that I was smart, and that I should continue. They had been the ones there for me, always pushing me to continue.

Provided motivation/inspiration. A number of participants also shared examples of how individuals motivated and inspired them to stay in college and complete their degree. One participant communicated that she wanted to set an example for her sister:

I wanted to be an example first to my sister, I have a sister that wanted to go to college too, and also my environment. Is someone who I want to, I especially want to respond to her financially, so I feel that going to college and continuing my education will help her in that sense.

Helped achieve personal goals. A couple of participants communicated that their personal motivation to succeed helped them achieve their personal goals. Here are a few examples:

It was hard for me because I was actually going through a depression at that time, but I somehow managed to stay in college... I just felt that I always knew that I could do better. Failure was not an option. Failing was not an option to me. I couldn't see myself outside of school.

Because I always kept myself motivated regardless of what was happening around me. I gave myself, you know, what I wanted. I knew what I wanted: to get a degree, you know I always kept that in my mind.

The third probe asked participants, "Did anyone help you learn how to navigate the college system?" As shown in Table 18, there was some variability in participants' responses. Half reported that they encountered little to no help and navigated college by themselves, while the other half reported that they received help 
from campus programs/orientation classes, college faculty/peers, and an International

High School counselor.

Table 18

Received Help Navigating the College System

\begin{tabular}{lc}
\hline Categories & $n(\%)$ \\
\hline $\begin{array}{l}\text { Had little to no help/navigated by } \\
\text { themselves }\end{array}$ & $6(50 \%)$ \\
$\begin{array}{l}\text { Support from campus } \\
\text { programs/orientation classes }\end{array}$ & $6(50 \%)$ \\
Help from college faculty/peers & $2(16.6 \%)$ \\
Help From High School Counselor & $1(8.33 \%)$
\end{tabular}

Note: Total does not equal $12(100 \%)$ because some participants provided multiple responses.

Had little to no help/navigated by themselves. Half of the participants

reported that they learned to navigate college by themselves because they received

little to no help at their community college. One participant expressed her frustration:

I would say not really because community college, they work, they have a mind of their own I will say. Because it's like you go to one office and once you get to that office they tell 'no you're in the wrong office, you have to go to this office,' and you go back to that office and they send you back to the first office, and they're like 'oh but this is what you needed yeah, yeah it's here.' So there's a lot of like miscommunication of people who don't really wanna help you, and don't really wanna support you, and will actually give you the hardest time.

She continued:

Even recently, I went to get a transcript and they were like, 'no we can't send this to your house.' Like gave me a whole like, didn't tell me I could actually pick it up and take it myself. So they don't give you as many options. 
Another participant shared a similar experience:

Not really. That was the hardest part because I didn't have anyone to go to in the beginning before the ASAP program. I didn't know where to go, who to ask, how to ask, I didn't know anything, so I basically teach myself how to navigate the work and know Blackboard and all that stuff. No one teach me how to do it. They say they have programs there, but you don't even know where they're located. How are you gonna find them?

Support from campus programs/orientation classes. A number of International High School graduates reported that their campus programs/orientation classes helped them navigate the college system. For example, one participant communicated that he received help from "the computer lab," whereas another communicated that he learned how to navigate college "during the first day of orientation.”

Help from college faculty/peers. A couple of participants also mentioned that college faculty members and peers helped them navigate the college system. One stated: "I would probably hear things from professors or other students, and I would ask for info."

Help from high school counselor. One participant indicated that her college counselor at the International High School was the one who helped her navigate college: "Well it was Jeremy, the college counselor for Ellis."

The fourth follow-up question asked participants to talk about how their campus programs/orientation classes, college faculty/peers, and the International High School counselor helped them navigate the college system. Table 19 illustrates participants' responses. 
Table 19

Ways Participants were Helped to Navigate College

\begin{tabular}{lc} 
Categories & $n(\%)$ \\
\hline $\begin{array}{l}\text { Provided logistical advice (e.g., how } \\
\text { to select classes) }\end{array}$ & $5(55.5 \%)$ \\
Provided academic support & $2(22.2 \%)$ \\
$\begin{array}{l}\text { Provided information about general } \\
\quad \text { resources in college }\end{array}$ & $1(11.1 \%)$
\end{tabular}

Note: Total does not equal $12(100 \%)$ because this category did not apply for some of the participants.

Provided logistical advice (e.g., how to select classes). Five of the participants shared that they received logistical advice such as how to select and register for classes, create their class schedules, and navigate the college website. Here is one example:

Like how to register for my classes. In college they gave me like 'okay, you have to register for your classes, you can do this way, or you can do it that way, you have to go to this website to set you up with a username and password, this is where you need to get your books, if you need to add a class this is how you add a class, this is what you do.' You know, tell us anything, they give you all the deadlines.

Provided academic support. Participants received academic support such as homework assistance, as well as academic advice on how to be successful in college. One participant explained:

They taught me how to work my way up in school. Well they gave me tutoring classes. I would go do my homework and they would help me out and prepare myself for tests and stuff like that. 
Provided information about general resources in college. One International

High School graduate communicated that she was told about the different resources available at her community college:

They told us like, the different resources they had, like the centers. The center does everything. They show you the different resources, the financial aid, everything! They show you everything there.

The fifth probe asked participants, "In your community college, to what extent were you mentored by a faculty member?" The majority of participants reported that they received mentorship from academic professionals such as professors, faculty/staff, and/or academic programs. However, two participants received minimal to no mentorship, and one was not able to remember contacts with a mentor (see Table 20).

Table 20

Mentorship Received in College

\begin{tabular}{lc}
\hline Categories & $n(\%)$ \\
\hline $\begin{array}{l}\text { Received mentorship from academic } \\
\text { professionals (e.g., faculty, staff, } \\
\text { academic programs) }\end{array}$ & $9(75 \%)$ \\
Received minimal to no mentorship & $2(16.6 \%)$ \\
Could not remember & $1(8.33 \%)$ \\
\hline
\end{tabular}

Note: $\mathrm{N}=12$.

Received mentorship from academic professionals (e.g., faculty, staff, academic programs). The majority of participants reported that they received mentorship from a number of academic professionals at their community college. For example, this participant communicated that she received mentorship from the advisor 
she had in one of the academic programs she was a part of: "At the ASAP program we always had to meet with the advisor every week, no, every month, up to twice a month."

Received minimal to no mentorship. Two participants felt that they received little to no mentorship while at their community college. This International High School graduate explained the lack of communication and minimal guidance he received at his college:

Well when I started we were part of this program where if you were like a freshman there's someone who's supposed to guide you through, like your classes and everything, so I would take classes with the same people, same students first semester, but I didn't think that was effective. They would pick all these classes for you that you didn't actually need, and if you already took them they would still make you take them again. Like there was like no oneon-one communication at all. It was more like you're thrown there and you're meant to take those classes and that's how you're supposed to be guided, you know. So I didn't think at all I received any help at all.

Could not remember. One participant was not able to remember if she received any type of mentorship at her community college.

Participants who responded that they received mentorship in their community college were also probed with, "Can you give me an example of the type of mentorship you received?" As seen in Table 21, participants received academic support/mentoring, personal and career-oriented support, encouragement, and help on how to become more organized and pay attention in classes.

Table 21

Examples of Type of Mentorship Received

\begin{tabular}{lc}
\hline Categories & $n(\%)$ \\
\hline $\begin{array}{l}\text { Provided academic } \\
\text { support/mentoring }\end{array}$ & $5(55.5 \%)$
\end{tabular}


Provided personal and career

$3(33.3 \%)$

-oriented support

Provided encouragement

$3(33.3 \%)$

Helped to become more organized

$1(11.1 \%)$ and pay attention

Note: Total does not equal $12(100 \%)$ because some participants reported more than one response category and this category did not apply to all.

Provided academic support/mentoring. Participants whose responses fell into this category conveyed that they received academic support/mentoring at their community college. For example, this participant spoke about the academic help he received from one of his professors:

When you used to be in her class she would always have the time you know, if you didn't understand it, she would have the time to explain to you to pass her class. She always was available.

Provided personal and career-oriented support. Three participants communicated that they received personal and career-oriented support such as what classes to take in college and the different career paths available. One participant described the help she received from her academic advisor:

She would help me pick my classes and tell me what would be best for me, tell me about my GPA, things I'm doing wrong, things I'm doing right, and how can I fix the things I'm doing wrong.... in that sense I would go once a week and it would help me a lot.

Provided encouragement. Other participants reported that they felt encouraged by faculty, staff, and/or academic advisors to stay in college and complete their Associate's degree. One participant spoke about the encouragement she received from one of her professors to apply to a 4-year college and continue her education: 
He was actually really helpful. He was the one who encouraged me to go to Plattsburgh to get a bachelor's there. And he walked me through the process of you know, how to apply, what I needed, and I think he was definitely one of the persons who actually helped me to get a degree.

Helped to become more organized and pay attention. One participant communicated that one of his professors helped him "be more organized" and "pay attention.”

The seventh probe asked participants, "How connected did you feel with professors?" Three categories developed from participants' responses (See Table 22). One third reported that they felt an overall connection with professors, while equal numbers reported that they felt somewhat connected, and felt little to no connection with their professors.

Table 22

Participants' Connections with Professors

\begin{tabular}{lc}
\hline Categories & $n(\%)$ \\
\hline Felt connected overall & $4(33.3 \%)$ \\
Felt somewhat connected & $4(33.3 \%)$ \\
Felt little to no connection & $4(33.3 \%)$
\end{tabular}

Note: $\mathrm{N}=12$.

Felt connected overall. Four participants reported that they felt an overall connection with all of their professors at their community college. One stated: "They were good. The connection was good. They were really helpful. They were really accessible."

Felt somewhat connected. Other participants reported that they felt somewhat connected with their professors and they felt connected to some professors more than 
others. Here is one example: "Some other professors were there just to teach, but I did get close to a couple of them. Some of them I'd say I was pretty close, I felt connected yeah."

Felt little to no connection. Participants whose responses fell into this category reported that they felt very little to no connection with their professors at their community college. Here is one account:

Not very much so. I'm the type to just get my work done and I don't really talk to professors like that. But other than that none of my professors. I barely remember their names honestly.

Here is another account: "Well they were there if you had any questions of course after classes, afterwards I wasn't that connected. I was not that connected.”

The eighth probe asked participants, "Can you share an instance in which you felt connected?" Three categories emerged from participants' responses (See Table 23). A number of participants reported feeling connected when professors provided academic and/or career advice inside and outside of class, while the rest reported feeling connected when their professors shared personal experiences, or when they had a good sense of humor.

Table 23

Examples of how Participants Connected with Professors

\begin{tabular}{lc}
\hline Categories & $n(\%)$ \\
\hline Academic/ career connections & $6(75 \%)$ \\
Personal connections & $3(37.5 \%)$ \\
Connected through humor & $1(12.5 \%)$
\end{tabular}

Note: Total does not equal $12(100 \%)$ because some participants reported more than one response category and this category did not apply to all. 
Academic/ career connections. A number of participants reported that they felt connected with their professors at their community college when they provided academic/career advice and offered extra help outside of class. One participant shared feeling connected to her professor because she was always available and helped her with her writing:

The professor I mention before. She, I could talk to her like any time she was available, like I could talk to her like she would just understand and especially if I have any situation where I was stuck. Like if I couldn't write because I couldn't find ideas, she would sit me down and just tell me, 'relax, and we are gonna think of ideas. I'm gonna help you.' And that's why I felt very connected to her because she was always there for me.

This other participant described how she felt connected to her accounting professor:

My accounting professor. I took two classes with him and he even said, he was telling me the way I could also be a professor if I wanted to, about different careers you can do as an accountant, as an auditor, as a tax person, and even going on to become a professor.

Personal connections. Some participants shared that they developed a personal connection to some of their professors through conversations outside of class or when professors shared personal experiences. Here are a few examples:

There was my English professor. Once I found out that she had cancer I kind of got closer to her. It was no longer a student-teacher relationship, it was more closer. And I kind of learned about their personal life a little.

My first professor yeah, my philosophy professor, I used to have a connection because I'm a Christian and since it's philosophy, I had a lot of questions and he had a lot of answers that I was you know, not happy with, and so we would have conversations.

Connected through humor. One participant shared that he felt connected with professors when "they were funny and used humor" because that created a better classroom environment for him. 
The next two interview questions examined the negative challenges, barriers, and/or unpleasant reactions International High School graduates experienced while in their community college. Participants answered one main question and one follow-up question. The first question asked participants if they had encountered negative challenges, barriers, or unpleasant reactions during their community college years. Five categories of responses emerged from participants' responses and the following section provides a description of each category (see Table 24).

Table 24

Perceived Challenges Experienced by Participants during College

Categories n(\%)

Negative interactions with individuals in college

$5(41.6 \%)$

Miscellaneous (e.g., hard to $4(33.3 \%)$ understand, different from high school, time management, personal challenges, lack of communication)

Did not encounter any challenges $3(25 \%)$

Language barrier $2(16.6 \%)$

Academic challenges $2(16.6 \%)$

Note: Total does not equal $12(100 \%)$ because some participants provided multiple responses

Negative interactions with individuals in college. A number of participants communicated that they experienced negative interactions with individuals in college such as professors, staff, and peers. For example, they stated that some of these 
negative interactions were related to professors having the same expectations for them

as they did for their native English-speaking students. Here is one example:

Some professors didn't understand the fact that you are not a native speaker so that made things complicated at times... Yeah or expect us to do just as well as the native speakers.

Another participant provided this example:

Negative in the sense that a professor wouldn't understand a certain situation and would just be a butthole about it, that's pretty much it... if I would tell a professor that I would be absent one day they wouldn't remember me or my name so when I came in the next day and I told them I was absent and I needed the work they would say, 'well you didn't even say you were going to be absent' and I said I was gonna be absent, so things like that.

Another participant talked about a negative experience he had with a staff member that worked at his college library:

I remember one time I went to the library and I was told by one of the members of the staff to leave a book behind, and I did, and she was like 'oh just place it there, I'll take care of it.' And then I noticed there's a stop in my account that I couldn't even register for classes so I go back to the library and they're like, 'you took a book that you weren't meant to take from the library but you took it anyway,' and I explained to her, I explained to this other person, and she didn't believe me. She wanted me to pay like a hundred and something dollars and I was like, well I can't do that because I didn't take the book, and she goes 'okay show me where you put it,' so I go show her where I put the book, come back, I find the book, she sees it. So I'm like, okay am I good to go? I have to go to class. She's like 'no, now you're gonna have to pay $\$ 10$ because I'm gonna to teach you a lesson... Yes. So it's more like, 'you look young so I'm going to take advantage of you, you don't speak English,' you know, perfectly.

Miscellaneous. Participants also shared a variety of other challenges they experienced in college such as a lack of communication between staff and students, time management, and college being very different from high school. For example, this participant spoke about spending a lot of time taking remedial classes when he did 
not need them because his school failed to inform him that they did not have his SAT scores on file:

Another challenge I faced was I was put in remedial math because for like the whole time I went there until my last semester, because like they never got my SAT scores. But I was never informed, so I remember one time I was like, okay I've been here since 2009 and took college classes I'm still here I don't understand why am I not graduating. And they were like, 'oh because you have to take this math class' and I was like, I've been in remedial math all this time and they said, 'you don't need remedial math you just need math 07 and pass,' and I was like, but I was never told that, how am I supposed to do, how am I supposed to know this? I need to graduate as soon as possible so whoever you need to speak to you're gonna speak to. So that was my only approach that you have to take in order for them to take you serious, and it sucks because that's not the type of person I am like why would I be something that I'm not because I need results. So that was like the biggest challenge because after graduating I spent so much money on those remedial classes that I didn't even need because they never got my scores and didn't inform me.

Did not encounter any challenges. Three International High School graduates communicated that they did not encounter any challenges in college.

Language barrier. Two participants communicated that their language abilities were a challenge for them in college. They stated that they had difficulties speaking up and felt embarrassed or worried about what others were going to think of them based on their accent:

I found myself at times in embarrassing moments because of my language barrier, since I didn't want to speak up because I was like, oh god people are going to start judging me.

My language has always been my barrier, but I always find to overcome it so I think everything I encounter I try to do the best I can... In my speech because I had an accent. So that's the only thing. When I had an accent people say they can't understand me well.

Academic challenges. Two of the participants also indicated that they experienced academic challenges during college. More specifically, they experienced difficulties passing certain classes or trying to understand the class content. This 
participant spoke about the challenges she experienced when she first started college in trying to understand class material:

In the beginning was hard because the class was different, and sometimes you didn't know the classes. So you need \{ed\}to ask questions about the classes, about what's going on.

To further obtain information about participants' negative challenges, barriers, and/or unpleasant reactions during their community college years, they were asked, "What most hindered you? Can you give me an example?" As seen in Table 25 the majority of participants had difficulty isolating one element that most hindered them during college, and their responses fell into six different categories.

Table 25

Things that Most Hindered Participants during College

Categories $n(\%)$

Language abilities/public speaking $4(33.3 \%)$

Time management $4(33.3 \%)$

Social interactions $2(16.6 \%)$

Funding college $2(16.6 \%)$

Personal struggles/immigration status $2(16.6 \%)$

Academic work $1(8.33 \%)$

Note: Total does not equal $12(100 \%)$ because some participants reported more than one response category.

Language abilities/pubic speaking. Issues regarding dual language proficiency were one of the most difficult things for several participants during their community college years. More specifically, they discussed that public speaking was 
much more difficult for them because English was their second language. Here are a few examples:

Just the fear of speaking up. My language barrier was the most difficult thing for me to deal with or you know, I just remember seeing all the other students expressing themselves properly, and at the time I didn't have the right words to say, so that used to frustrate me.

I had a speech class and I would get nervous to the point where I wouldn't want to do it. I had to force myself to do it, so college really made me more comfortable.

Time management. Several participants found that balancing their academic work, jobs, and other various activities was what most hindered them during college. Here is one account:

I will say because my job, I had work through college. I had college in the morning and then at night go to my job, and then homework. So that was very challenging.

This other participant spoke directly about the challenge of having to study for all of her class midterms and finals at the same time:

Every time we had a midterm or final, they were all together, so I had to study for all of them at the same time. They were always at the same time - two or three at the same time.

Social interactions. Two of the participants reported that what most hindered them during college was not being able to socialize with their classmates or professors as much as they would have like to. This participant explained that she was closer to her classmates in high school and used to work with them in groups, something she did not get to do in college:

Well I would say socializing with my classmates because I was so used to in high school to socialize with my friends in the sense that we worked in groups and stuff like that. It was kind of hard since when I went to college-I actually became a different student. In high school I was very social and talkative, but 
in college I would sit down and relax and just do my homework and my work, so I think that was very hard for me, you know.

Funding college. Two International High School graduates also reported that what most hindered them during college was paying for their community college tuition. This participant stated: "The most difficult thing for me was actually affording school."

Personal struggles/immigration status. Participants also felt that personal struggles that come along with being an undocumented student or dealing with a mental health disorder was what most hindered them during college. Below an International High School graduate explains her disappointment for not being able to receive scholarships due to her immigration status:

So many scholarships where like coming up to me like telling me, 'oh you're available for this, this, and this. These sources are available for you, but we can't actually give you any money because you don't, you're not,' you know, I didn't have a green card, I didn't have a social, so like they couldn't offer me anything else which was even more disappointing because if I would have had it then I would have been fine, you know, so that was my biggest challenge.

Academic work. One participant found that academic work was the most difficult part of college. More specifically, he reported that "writing" was what most hindered him during his community college.

Research Question 2(b): What implications do second language abilities have for Hispanic immigrant-ELLs during their time at their community college?

In response to this question, participants were asked how their second language abilities helped them or hindered them during their community college years. The question yielded eight response categories. Specifically, the majority of participants reported that their second language abilities were helpful and beneficial, while three 
participants felt that their second language abilities were not helpful or beneficial to them. Table 26 provides a breakdown of this information.

Table 26

Ways in Which Second Language Abilities Helped/Hindered Participants During College

\begin{tabular}{lc}
\hline Categories & $n(\%)$ \\
\hline $\begin{array}{l}\text { Second language abilities were } \\
\text { helpful/beneficial }\end{array}$ & $9(75 \%)$ \\
$\quad \begin{array}{l}\text { Helped other Spanish-speaking } \\
\text { students }\end{array}$ & $4(44.4 \%)$ \\
Helped academically & $3(33.3 \%)$ \\
$\quad \begin{array}{l}\text { Helped with social } \\
\text { interactions/communication with } \\
\text { others }\end{array}$ & $2(22.2 \%)$ \\
$\begin{array}{l}\text { Second language abilities were not } \\
\text { helpful/beneficial }\end{array}$ & $3(25 \%)$ \\
Difficulties with translation & $2(66.6 \%)$ \\
Not being understood & $2(66.6 \%)$ \\
Struggled with public speaking & $1(33.3 \%)$
\end{tabular}

Note: Total does not equal $12(100 \%)$ because some participants provided multiple responses.

Second language abilities were helpful/beneficial. Many International High School graduates felt that their second language abilities were helpful/beneficial during their time at their community college, as illustrated by the following comment: "My skills to speak both languages was resourceful I will say." 
Helped other Spanish-speaking students. Four participants indicated that their ability to speak Spanish allowed them to help other international-Spanishspeaking students. Here are two examples:

Help other people, my classmates, who may not have spoken as much English as I did. So I would help them out.

That helped me a little bit I think...They used to put me to help other exchange students sometimes that were kind of learning English so I was kind of helping them with that.

Helped academically. A number of International High School graduates felt that their second language abilities helped them academically because they were able to do research in Spanish or were able to take Spanish as their second language class requirement. This participant explained that she was able to do research and read articles in Spanish in order to complete some of her class assignments:

I think it was a really great advantage because I had a lot of research and stuff like that that I would do about Spanish countries...I needed to read Spanish in order to read an article.

This other participant explained:

It was very helpful. We had to take two language classes and I chose Spanish for that, and I got really involved in both classes.

\section{Helped with social interactions/communication with others. Two}

participants communicated that their second language abilities helped with social interactions/communication with others. As the following illustration indicates, one felt that her second language abilities were helpful because it helped her communicate with other individuals in college:

It was somewhat helpful because I was able to communicate with other students who like couldn't understand me as well in English as they could in Spanish, or like vice versa, so I will say that's a way that it helped me. 
Second language abilities were not helpful/beneficial. Three International

High School graduate reported that they felt their second language abilities were not helpful/beneficial while they were at their community college. For example, this participant stated: "I just remember seeing it as a barrier more than a help."

Difficulties with translation. Two participants indicated that their second language abilities were not helpful/beneficial because they had difficulties translating some words from English to Spanish. This participant stated: "It was hard for me because some words were just too complicated to translate. Or I would mix both languages."

Not being understood. Two participants also reported that they did not find their second language abilities to be helpful during college because other people had trouble understanding them. This participant explained that individuals in college had difficulty understanding him because he spoke English with an accent:

When I speak it, sometimes I have an accent, so it was difficult for them to understand me. But I always make sure I repeat myself so they can understand what I'm saying.

Struggled with public speaking. One International High School graduate communicated that she struggled with public speaking, therefore she did not find her second language abilities to be helpful during college. She explained:

I think if I had spoken English only and not Spanish I would have more, I mean less, struggle as in public speaking because that was the hardest part for me. But I think if English had been my first language I'd be more comfortable.

Research Question 3: Why Hispanic immigrant-ELLs may stop at the Associate's degree and not continue through to a baccalaureate degree? 
International High School graduates were asked to provide their thoughts regarding the reason(s) many Hispanic immigrant-ELLs may stop at the Associate's degree and not continue through to a baccalaureate degree. Their answers fell into five categories as illustrated in Table 27.

Table 27

Reasons Hispanic Immigrant-ELLs May Stop at the Associate's Degree

Categories $n(\%)$

Financial reasons $8(66.6 \%)$

Familial obligations $6(50 \%)$

Miscellaneous (e.g., language $3(25 \%)$ barriers, Associate's degree is enough, they do not want to, they received no guidance)

College is difficult $2(16.6 \%)$

Immigration status $2(16.6 \%)$

Note: Total does not equal $12(100 \%)$ because some participants reported more than one response category.

Financial reasons. Several participants communicated that a main reason many Hispanic immigrant-ELLs stop at the Associate's degree and do not continue through to a baccalaureate degree is because of financial reasons. They stated that four-year colleges are more expensive than community colleges, making bachelor's degrees less attainable for Hispanic immigrant-ELL students. One participant summarizes this point:

I will say one thing is because of money. You know, once you go for your bachelor's it's a little more expensive. You have to take out loans... Honestly because it's more money for the person. 
Another participant described that college is expensive, and it is very difficult for students coming from single-parent homes to pay for it:

Well in my case it's all about money. And sometimes we come from only a one-parent family, so it's really hard for them to come up with money, and it's hard for them to put their kids through college, and they might just go to a twoyear college. And then they cannot afford the other one.

Familial obligations. Half of the participants stated that they believe the reason Hispanic immigrant-ELLs stop at the Associate's degree and do not continue through to a baccalaureate degree is because they have familial obligations such as family members they need to support. For example, this participant explained that within the Hispanic culture, it is expected that the younger ones provide financial support for their family members:

I will say within our culture there are so many families who start early. There's so many people who get married at like age of 18 and have kids. Many of them already come with kids so they're part of big families, and it's very challenging for them to be able to help them, at the same time of like going to school, and you know, this, school takes so much time from other priorities, so I feel like not everybody has the same you know, I wouldn't say the same abilities, but everyone goes through different things. And within our culture it is known that we're there to support our families and one of those, the major things is to be able to provide for them. So in many cases you have family members who are sick or older or need you to be around, or need you to support them, so I will say it's hard when you have all these other people also like relying on you. I remember in high school with kids who were like 20 something because they were pushed back and they have families, and have to graduate and go to school, but at the same time they had to provide for their families. So I will say those are like the main things that in our culture and our society that stops us from continuing our education.

A second participant made a similar point:

Well I think some of them because they have families, and they have to work for their family to make money, so to work. And some have family outside of United States, they have to send money over there too. That's what I think why they sometimes might, like me, I couldn't go, I registered for Brooklyn College but I didn't finish because I had to go to work and have a family of five. I had to help my husband, I had to support him, I had to go to work. 
Miscellaneous. Participants also shared a number of other reasons Hispanic immigrant-ELLs may stop at the Associate's degree, such as not having enough guidance to apply to four-year colleges, having a language barrier, and believing that an Associate's degree is enough to get a job. Here is one account:

I guess they think that it's enough. Some people think that an Associate's is enough to get a good job, or I don't know, they just don't wanna do it.

College is difficult. Two participants said that they believe the reason Hispanic Immigrant-ELLs don't continue through to a baccalaureate degree is because college is difficult. For example, this participant stated that four-year colleges are harder than community colleges:

College is hard, it's harder than community college. And it took a lot of time. Homeworks are harder than community college, and it took a lot of time, like I say, to do the homework, do the projects, the class, too many things, it depends also in the major that they want.

Immigration status. Two participants also communicated that there is a large number of Hispanic immigrant-ELL students that are undocumented in the U.S., and that makes it more difficult for them to attend four-year colleges. This participant illustrates this point:

Sometimes is due to not being legal in the country because I had a friend actually who stopped. She was going to college to Kings Borough with me, she stopped because she was illegal, and she felt that, well, what's the point of getting a bachelor's degree if she was not able to work in the country.

Research Question 4: What advice do International High School graduates have for other immigrant-ELLs to help them succeed in community colleges?

Every participant was asked to reflect on his or her community college experiences and to provide advice to other immigrant students whose native language 
is not English to help them succeed in community college. Table 28 provides a summary of participants' responses that fell into four categories.

Table 28

Recommendations Provided by Participants to Help Students Succeed in College

Categories $n(\%)$

General encouragement $8(66.6 \%)$

Make use of resources/ask for help

Academic/language related advice

Miscellaneous (e.g., immigrants $2(16.6 \%)$ have rights, research the school before attending)

Note: Total does not equal 12 (100\%) because some participants provided multiple responses.

General encouragement. A large number of participants indicated that they would encourage other immigrant students whose native language is not English to help them succeed in community college. One indicated that she would tell them, "just to continue pursuing their dreams" and "try to do everything right and never give up." Another one indicated that she would tell them the following:

To show themselves that they could do certain things, and not to do it for people because you are always gonna be disappointed in people, you're always gonna be disappointed in your past, but you do it for yourself, and you have that passion for yourself.

Another participant spoke directly about not giving up even if language is a barrier:

I would tell them to, regardless of their language barrier, to never give up... Don't let any negative comments or just your fear of the language barrier stop you from pursuing that degree. 
Make use of resources/ask for help. A number of International High School graduates brought up the importance of making good use of the resources available in their community college, including asking for help. For example, one participant communicated that she would recommend to: "keep looking and searching until you get what you need." Another participant highlighted the importance of seeking and utilizing the resources available to them:

To look for help, more because they do have a lot in college, like they really offer you a lot of opportunities for you to take, you know? Extra classes or workshops, but there's a lot of resources. We just have to, they're not gonna come to us unless we go and ask for it.

Academic/language related advice. One third of the participants indicated that they would provide academic/language related advice to other immigrant-ELLs to help them obtain their Associate's degree. For example, one participant indicated that she would recommend for them to "learn English and understand more about the language," while another one indicated that she would tell them to "know all the requirements before you graduate." Another participant spoke about the benefits of speaking two languages:

I would tell them the language shouldn't be a barrier because outside now days they are hiring people that speak more than one language, so it is important for them to continue and pursue what they want to be.

Miscellaneous. Participants also shared other types of advice. For example, this participant talked about the importance of getting acquainted with the college staff and departments:

I will say to do a lot of research about your school before you go in, and actually contact to somebody from like, even like someone from each department or the department you're going to like whatever your major is, like get to know them so they could actually help you and put a face to your name that way when you go in or call or you have any questions, they will be able to 
help you because they'll be familiar with you instead of like you know, the school is gonna have so many other students it's not only gonna be you, so I would say get to know your school.

Another participant stated that she would remind immigrant students that they also have rights in the U.S:

And we also have rights here even though we are immigrants, even though in my case I'm an undocumented student so I thought I would never reach this, but I did. And it's not easy, but yes.

\section{Additional Findings}

The last interview question asked participants if there was any additional information that they would like to share that would allow for a more complete understanding of their experience going to a community college as a graduate of an International High School. Three participants decided to provide additional advice to other immigrant students for them to pursue higher education, answering the previous interview question: "Reflecting on your community college experiences, what advice would you give immigrant students whose native language is not English to help them succeed in community college?" One participant decided to emphasize the importance of promoting the college experience in high school, and the rest did not have anything else to add. Table 29 provides a breakdown of participants' responses.

Table 29

Additional Findings

Categories $n(\%)$

No additional information

$8(66.6 \%)$

Encouragement to pursue/continue

$3(25 \%)$

higher education 
Promote college experience in high school

$1(8.33 \%)$

Note: $\mathrm{N}=12$.

No additional information. The majority of participants felt there was no additional information they needed to add to their interview that would allow for a more complete understanding of their experiences.

Encouragement to pursue/continue higher education. Three participants decided to provide additional encouragement to other immigrant-ELL students for them to pursue and continue higher education. For example, this participant stated that immigrant-ELLs should not feel intimidated by their accent, and instead, should feel proud of speaking two languages and continue their education:

I don't think nothing can stop you from getting what you want except you. I think it's all in the mind. If you really put your mindset to doing something, forget about it, you will do it. People right now don't even reach into imagination to actually accomplish their dreams, you know, they see what the system is offering them. You just can't stop there because, you know, you are Hispanic, you have an accent, people graduate every day or every year from college who don't even have an accent, and stuff like that. You know, that's what really, as Hispanic people, really intimidates us. When we see that we can be less than someone, but it's not true, we can be, if anything we speak two languages, we have advantages that we need to take, we need to take advantage of them.

Promote college experience in high school. One participant decided to add that the college experience should be promoted in high school. 


\section{CHAPTER 5}

\section{DISCUSSION}

The present investigation explored how the International High School experiences of Hispanic immigrant-ELLs helped to foster their readiness for community college. Through semi-structured interviews, participants described the challenges and supports they experienced at their community college, implications of their second language abilities for their studies, and the reasons Hispanic immigrantELLs may stop at the Associate's degree and not continue through to the baccalaureate degree. They also provided valuable suggestions for other Hispanic immigrant-ELLs to help them succeed in community college.

\section{Educational experiences at the International High Schools}

Participants described the ways in which the International High Schools prepared them for community college. The majority of participants stated that they had a generally good experience at their International High School, and that they found helpful and supportive individuals such as teachers and classmates within the schools. These findings mirror those of Murillo (2015) who found that the International High Schools created an engaging and socially supportive environment for its graduates. The findings from the current study are of great importance because research has shown that unlike the International High Schools, secondary institutions often times do not understand and/or are not well equipped to educate such a complex and challenging group of students (Orozco et al., 2010).

In addition, International High School graduates talked about the advantages they experienced while working within a supportive and collaborative environment. 
Most International High School graduates communicated that the International High Schools prepared them for community college through academic and language learning related activities, such as writing assignments, projects, and portfolios. In addition, many mentioned that the International High Schools provided them with a general preparation for college, including the opportunity to take college courses, and to explore possible career choices by participating in internships. These findings are consistent with the findings from the Murillo (2015) study, where it was found that the International High Schools helped participants develop specific academic skills that prepared them for four-year colleges, such as learning English, problem solving, and writing.

A very important finding regarding participants' community college preparation was the encouraging and positive messages they received at the International High Schools about going to college. Eleven out of twelve participants reported that they received positive and encouraging messages from a number of individuals at the International High Schools (e.g., teachers and guidance counselors) about going to college. Moreover, half of the participants communicated that they received personal preparation for college, which included how to apply for college, and how to seek help while in college. These findings are consistent with a previous study conducted by Jaffe-Walter and Lee (2011) who found that teachers and staff at the International High Schools spoke constantly to students about going to college, which created a college-going culture for them. As seen in the present study, the encouraging messages about going to college positively impacted the participants, and gave them the motivation to enroll and attend a community college. 
Participants also shared whether or not the International High School provided them with the necessary skills to complete their Associate's degree, More specifically, they discussed the skills they acquired at the International High Schools that contributed to their community college completion. The majority of participants felt that the International High Schools prepared them for community college by providing them with the academic and language preparation needed to complete their Associate's degree. These findings are noteworthy because research has shown that most secondary institutions do not appear to know how to academically prepare immigrant-ELL students for college, often times excluding them from rigorous academic classes (Callahan, 2005; Olsen, 1997; Valenzuela, 1999). As a result of this, students are prevented from learning specific academic and language related skills that are needed for the completion of a college degree. It is also important to note that more than half of the participants in the study felt that the support and encouragement they received from individuals at the International High Schools was what helped them complete their Associate's degree.

Past research (Fine et al., 2005) showed that about 90\% of International High School graduates were accepted to colleges upon their high school graduation. In the present study, participants were asked to share their thoughts on why the International High Schools have had such a high college acceptance rate. The majority of participants thought that the high college acceptance rate is due to parental and teacher influences. Participants felt that teachers and parents are very influential in students' lives, and they encourage them to do well in high school and enroll and attend college. Considering the increasing number of jobs mandating a college degree, researchers 
have argued that schools need to create cultures where all students can foster strong relationships with educational personnel who can provide good social support (Conchas, 2006; Gandara, 1999; McDonough, Antonio \& Trent, 1997). According to Koyama (2007), students who attend secondary institutions that value social networks do better in school and have a higher chance of attending college than students who do not attend such institutions. As seen from the present study, participants believed that parental and teacher influences as well as students' personal motivation to continue their education, are the main reasons the International High Schools have had such a high college acceptance rate.

\section{Educational Experiences During Community College}

Participants described the ways their high school life differed from their community college life with regards to their educational experiences. Most commonly, participants reported that in comparison to community college, the International High School provided a more comfortable and supportive environment for them. Some participants reported that they had to become more independent in college, struggled with time management, and that community college was more challenging than high school. These findings are very important because research suggests that the transition to college is a significant and critical period for immigrant students. This period is often characterized by academic, cultural, and psychological challenges (Chickering \& Reisser, 1993). Therefore, the present study calls for community colleges to create comfortable, engaging, and welcoming environments for immigrant students to help facilitate their academic success. 


\section{Perceived supports experienced during community college. International}

High School graduates revealed the supports they experienced while completing their Associate's degree. One of the most important findings is that the majority of International High School graduates received support from academic programs within their community college, such as the writing center and outside-of class tutoring. In addition, the majority reported that they also received support from faculty/professors. Participants communicated that faculty/professors provided academic and financialaid advice, as well as other types of educational opportunities to help them succeed in community college. These findings are very important to note because previous studies with Hispanic/Latino college students have confirmed the importance of strong student-faculty interactions (e.g., Anaya \& Cole, 2001). In fact, several researchers have argued that high quality student-faculty interactions can help facilitate college student persistence and achievement (Pascarella, \& Terenzini, 2005; Stebleton, Soria, Aleixo, \& Huesman, 2012). It is evident from the present study that participants felt that having the support and encouragement from academic programs and faculty/professors contributed to their success in community college.

Another important finding from the current study is that the overwhelming majority of International High School graduates felt that their family members and friends were the ones who kept them in college. They stated that their family members and friends provided significant encouragement for them to complete their Associate's degree. These findings do not come as a surprise since earlier studies have shown the importance that family and friends have in the educational success of Hispanic students in college (Rodriguez, Mira, Myers, Morris, \& Cardoza, 2003; Solberg \& 
Villareal, 1997). For example, Kim's (2009) qualitative study reported that immigrant students tended to rely on peer networks of the same ethnicity when seeking assistance in adapting to the college environment.

Perceived challenges experienced during community college. Participants also experienced several challenges, barriers, and unpleasant reactions while completing their Associate's degree. The most commonly identified challenge was negative interactions with individuals in college, such as professors and staff. For example, participants reported that they experienced negative interactions with professors because professors had the same expectations for them as they did for their native English-speaking students. Previous literature has shown that immigrant-ELL students tend to be at a disadvantage with respect to academic preparation compared to their native-born English-speaking peers (Pascarella \& Terenzini, 1991). Other studies have suggested that immigrant students who do not feel a strong institutional connection to their college may become at risk of dropping out when they encounter challenges at their community college (Crisp \& Mina, 2012). These findings highlight the importance of providing effective programs that can address the diverse needs of this highly heterogeneous group of students.

\section{Implications of second language abilities during community college.}

Another major finding is that the majority of participants felt that their second language abilities were helpful/beneficial during their community college years. They indicated that their ability to speak Spanish helped them academically, helped facilitate their social interactions with other Spanish-speaking students, and gave them the opportunity to translate for other international-Spanish-speaking students in their 
community college. These are very surprising findings since research has shown that the lack of English proficiency is one of the biggest obstacles for immigrant-ELLs in college (Erisman \& Looney, 2007). These findings demonstrate that students' native languages have a strong influence on their academic and social performance.

Therefore, community colleges should encourage immigrant-ELL students to utilize their native language in order to help improve their English skills, as well as to facilitate their academic success and social adjustment. In addition, awareness of cultural differences that affect immigrant students can help faculty and academic counselors focus on the specific needs of this population.

\section{Reasons Hispanic Immigrant-ELLs Stop at the Associate's Degree}

International High School graduates were asked to provide their thoughts regarding the reason(s) many Hispanic immigrant-ELLs may stop at the Associate's degree and not continue through to a baccalaureate degree. Eight out of twelve participants communicated that the main reason Hispanic immigrant-ELLs stop at the Associate's degree is because of financial reasons. They stated that four-year institutions are more expensive than community colleges, which is why Hispanic immigrants are less likely to attend four-year institutions. These findings support

previous literature, which suggests that community colleges have been the destination of choice for immigrant students because they provide low-cost tuition (Cohen $\&$ Brawer, 2003). The affordability of higher education remains a critical factor for immigrant students wanting to earn a college degree (Kim \& Diaz, 2013). For many immigrant students, it is becoming more difficult to pay for higher education because of the gap between increasing tuition prices and insufficient financial assistance (Kim 
\& Diaz, 2013). As a result, community colleges have become a good choice for the immigrant population who wish to pursue an affordable college degree (Kim \& Diaz, 2013; Teranishi et al., 2011).

Furthermore, half of the participants communicated that they believe the reason Hispanic immigrant-ELLs stop at the Associate's degree and do not continue through to a baccalaureate degree is because they have familial obligations such as family members they need to support. Prior research has shown that Latino students struggle between familial obligations and the requirements of school, which can contribute significantly to a difficult academic adjustment and low retention rates for these students (Lopez, 1995; Vasquez, 1982). The findings from the present study are particularly important because they speak to the competing family responsibilities and school responsibilities many Hispanic immigrant students currently experience.

\section{Recommendations to other Immigrant-ELLs}

Participants were asked to reflect on their community college experiences, and to provide advice to other immigrant students to help them succeed in community college. Almost all of the participants provided general encouragement, as well as advice to make use of resources in their community college - including the importance of asking for help. These findings highlight the importance of being mindful of the needs of immigrant students who attend community colleges by providing adequate social, academic, and emotional support. In addition, these findings help us become better acquainted with the supportive factors that help immigrant students through the obstacles they face in community college. 


\section{Limitations and Methodological Considerations}

There are also a number of limitations that need to be discussed when interpreting the findings of the current study. The sample size may be considered a limitation. A larger sample size would have allowed for a more diverse group of International High School graduates and therefore, provided additional information regarding the experiences of Hispanic immigrant-ELLs who completed an Associate's degree. In addition to the small number of participants, another limitation is that the sample included a disproportionate number of females and males (10 females and 2 males) despite the fact that International High Schools have a comparable number of female and male graduates. Furthermore, the unique characteristics of the current sample (e.g., participants who attended one of the existing International High Schools, completed an Associate's degree, etc.) may limit the transferability of the data across different groups. It is possible that because most participants in this study attended only International High Schools located in New York City, the study may have attracted International High School graduates with similar experiences. However, these results should reflect the individual experiences of the participants in this study, and the findings should not be generalized to represent the experiences of all International High School graduates who attended a community college and obtained an Associate's degree.

Another limitation is that participants' responses to the questions were brief and cursory. This was potentially the result of this study being a retrospective study, or because the interviews were conducted by phone rather than in person. This could also be because the majority of participants did not have a rich community college 
experience as they noted to have had many conflicting family and work responsibilities while they were completing their Associate's degree.

It is also important to discuss ways in which the researcher can influence the meanings of findings throughout the research process, which is referred to as reflexivity (Hale, Treharne, \& Kitas, 2007). Reflexivity can be a beneficial part of the research process because the researcher can provide insight knowledge when analyzing the results of the study (Camic, Rhodes, \& Yardley, 2004). However, researchers have also argued that reflexivity can be problematic because research should be impartial and unbiased, without personal involvement from the part of the researcher (Willig, 2001). Thus, it is important for me to acknowledge how my own values, background, ethnicity, and experiences, may have impacted how the study was conducted and interpreted. I believe that my ethnicity and educational background provided an advantage. I was able to connect and relate to many of the participants' experiences. I am also very passionate about working with Hispanic immigrant-ELLs and my enthusiasm may have been conveyed through my tone of voice. This may have led participants to share more sensitive experiences with me than they probably would have shared with someone from a different ethnic or educational background. However, this could have led to confirmation bias and may have influenced the way participants communicated their stories.

\section{Strengths and Directions for Future Research}

The present study also has several strengths. To date, this is the first research study to explore how the International High School experiences of Hispanic immigrant-ELLs helped to foster community college readiness. In addition, this is the 
first research study to have examined the supports and challenges experienced by International High School graduates while they were completing an Associate's degree. Results from this study strongly suggest the need to develop awareness of the life experiences that Hispanic immigrant-ELLs encounter at community colleges in order to create a more welcoming and supportive environment for them. It also provides higher education institutions with important and useful information to help foster the academic experiences of immigrant ELL students.

Furthermore, results from this study suggest that the International High Schools' holistic approach to educating immigrant-ELLs has been successful in helping immigrant-ELLs achieve academic success. Therefore, community colleges should consider adapting a more holistic approach, like the one at the International High Schools, in which they provide a close-knit, nurturing community that encourages and celebrates immigrant students' native languages and cultures while providing them with the necessary academic support. For example, community colleges should organize cultural activities such as international dances and food festivals to help embrace students' cultural backgrounds. Additionally, community colleges should encourage immigrant students to speak, read, and write in their native language by designing inside and outside of class projects that incorporate students' native languages. This holistic approach would help to increase immigrant students' sense of community and connectedness within their community college and help improve their academic experience.

Future research may look to explore the high school and community college experiences of other ethic/racial minority groups who attended and graduated from an 
International High School and obtained an Associate's degree. In addition, it would be interesting to look at the experiences of Hispanic immigrant-ELLs that attended and graduated from "typical” U.S. high schools and then pursued and completed an Associate's degree. According to the National Center for Education Statistics (2016), the total number of ELL students that were enrolled in "typical" public secondary schools in 2013-2014 was 793,605. Since the number of ELLs who attend U.S. "typical" schools is so large, their experiences can be compared to the experiences of the International High School graduates reflected in this study. This information would be of great value since it may help us become better acquainted with the realities of educational opportunities available to immigrant-ELLs attending typical U.S. high schools. This information can also help create recommendations to make the experiences of immigrant-ELLs attending typical U.S. high schools more equitable and better suited to their needs. For example, the present study shows the importance of feeling connected in high school and developing positive and meaningful relationships with teachers and other educational personnel. These connections helped to empower the participants to attend college and further their education. Typical high schools may benefit from creating positive and meaningful connections with their ELL student population in order to better foster their learning and help them transition to college.

In addition, it would be helpful to obtain information about how faculty and staff in community colleges handle obstacles experienced by immigrant-ELL students (e.g., academic obstacles, negative social interactions, language barrier, immigration status etc.) when these are brought to their attention. Given that community colleges 
have become the destination of choice by many immigrant students, it is important to gain a better understanding of the ways community colleges are helping and contributing to the success of these students. 


\section{Appendix A - Demographic and Personal Background Questions}

1. What is your gender?

2. What is your age?

3. What is your country of origin?

4. What is your race/ethnicity?

5. What is your native language(s)?

6. How long have you lived in the United States?

7. How old were you when you came to the United States?

8. What was the reason for immigrating to the United States?

9. What International High School did you attend?

10. What year did you graduate from the International High School?

11. What community college did you attend?

12. What year did you graduate from the community college with an Associate's degree?

13. How many years did it take you to complete your Associate's degree?

14. Why did you decide to attend a community college?

15. Are you a first generation college student?

16. Have you pursued a Bachelor's degree or advanced degree? 
17. Did you graduate with a Bachelor's degree or advanced degree?

18 . What is your current occupation?

19. How many years of formal education did you receive in your home country?

20. Have you faced interruption in your formal education? If so, when and for how long? 


\section{Appendix B - Interview Guide}

[Hello, may I speak to please.] This is Pamela Murillo; I am a doctoral student from the Psychology Department at the University of Rhode Island. Today I would like to talk with you briefly about your educational experiences. Thank you again for agreeing to participate. As noted in the consent form, participation in this study is voluntary and you may refuse to answer any question and/or discontinue the interview at any time. Let's begin.

(Ensure that equipment is working properly, if technical difficulties arise, re-schedule the interview with the participant.)

1) Tell me about your life at the International High School? What was it like being there?

2) How did the International High School prepare you for college? What educational activities did you engage in that prepared you for college?

Probes include:

A. What messages did you receive at the International High School about going into higher education?

B. Do you think the International High School provided you with the necessary skills to complete your Associate's degree, and why?

C. Did anyone at the International High School give you any advice about college? If so, what advice did you receive?

3) Past research shows that about $90 \%$ of International High School graduates were accepted to colleges upon their high school graduation. Why do you think the International High Schools had this rate?

4) How did your high school life differ from your college life with regards to your educational experiences?

Probes include: 
A. Can you talk about your English skills in high school and how they compared to what they were when you were in college?

5) Did you encounter supports that helped you complete your Associate's degree? Probes include:

A. What are the top two or three things or people that helped keep you in college? How did they help you?

B. Did anyone help you learn how to navigate the college system? And how did that person(s) help you?

C. In your community college, to what extent were you mentored by a faculty member? Can you give me an example of the type of mentorship you received?

D. How connected did you feel with professors? Can you share an instance in which you felt connected?

6) How did your second language abilities help you or hinder you during your community college years?

7) Did you encounter negative challenges, barriers, or unpleasant reactions during your community college years?

Probes include:

A. What most hindered you? Can you give me an example?

8) Reflecting on your community college experiences, what advice would you give immigrant students whose native language is not English to help them succeed in community college? 
9) Why do you think many Hispanic immigrant-ELLs stop at the Associate's degree and do not continue through to the baccalaureate degree?

10) Is there any additional information that you would like to share that would allow for a more complete understanding of your experience going to community college as a graduate of an International High School?

Thank you very much for sharing your experiences with me. Your input has been very helpful and I appreciate your willingness to participate. Please let me know if you would like a copy of my study results. Yes__ No__Where can I send them to you?

Where can I send you the gift card?

And, might you know any other International High School graduates who also graduated with an Associate's degree who may be interested in participating in my study? If so, please let me know his/her contact information.

Again, my sincerest thanks for your time and participation. 


\section{Appendix C - Cover letter to Principals \& Teachers}

\section{THE}

UNIVERSITY

OF RHODE ISLAND

ARTS AND SCIENCES

THINK BIG

Dear

I am a doctoral student in the School Psychology program at the University of Rhode Island. As part of my dissertation research project, under the direction of my major professor, Dr. Margaret Rogers, I am conducting a study on the educational experiences of former International High School students who are Latino and who attended a community college and completed an Associate's degree. I am writing to ask you to consider referring your former students for possible participation.

Participants will take part in audiotaped phone interviews relating to their high school and community college experiences. Any information they provide will be strictly confidential and their name will not appear in any reports resulting from the study. The interview will address questions about participants' educational experiences. More specifically, they will be asked questions about being a graduate of an International High School as well as questions about their educational experiences during their time at their community college. The interview is expected to last about 30-45 minutes. A second interview will be scheduled only if supplementary information is needed or if technical difficulties arise during the interview. Participants will also receive a \$20 gift card as a thank you for their participation.

Individuals that meet the following criteria are eligible to participate:

- Former International High School students who completed all four years at an International High School.

- Graduated from an International High School between the years 20012013.

- Completed an Associate's degree at a community college in the United States.

- Identify as Hispanic/Latino.

Please forward my contact information to your alumni network and to all individuals that may be interested in participating in this study. Please feel free to contact me with any questions you may have. I can be reached at (347) 495-05-46 or at pmurillo@my.uri.edu. This research has been approved by The University of Rhode Island Institutional Review Board.

Thank you for your time and consideration. We appreciate your help! 
Sincerely,

Pamela Murillo, M.A.

Margaret Rogers, Ph.D.

(347) 495-0546

pmurillo@my.uri.edu

Doctoral Student

School Psychology Program

(401) 874-7999

mrogers@mail.uri.edu

Full Professor

University of Rhode Island

School Psychology Program

University of Rhode Island 


\title{
Appendix D - Cover Letter to Participants
}

\author{
THE \\ UNIVERSITY \\ OF RHODE ISLAND \\ ARTS AND SCIENCES
}

THINK BIG

DEPARTMENT OF PSYCHOLOGY

Chafee Hall, 142 Flagg Road, Kingston, RI 02881 USA $\quad$ p: $401.874 .2193 \quad$ f: $401.874 .2157 \quad$ uri.edu/artsci/psy

Dear

I am a doctoral student in the School Psychology program at the University of Rhode Island. As part of my dissertation research project, under the direction of my major professor, Dr. Margaret Rogers, I am conducting a study on the educational experiences of former International High School students who are Latino and who attended a community college and completed an Associate's degree. I am writing to ask for your time and participation in this research project. If you choose to participate, you will take part in audiotaped phone interviews relating to your high school and community college experiences. Any information you provide will be strictly confidential and your name will not appear in any reports resulting from this study.

The interview will address questions about your high school and community college experiences. More specifically, questions about being a graduate of an International High School as well as questions about the educational experiences you had, including supports and challenges you experienced, during your time at the community college you attended. In addition, the interview will address questions about the implications of your second language abilities during college, reasons you think Hispanic immigrant-ELLs may stop at the Associate degree and do not continue through the baccalaureate degree, as well as the type of advice you may have for other immigrant-ELLs to help them succeed in community colleges.

The interview is expected to last about 30-45 minutes. I am interested in your unique experiences and I encourage you to freely share them during the interview. A second interview will be scheduled only if supplementary information is needed or if technical difficulties arise during the interview. If you choose to participate, you will be sent a $\$ 20$ gift card as a thank you for your participation upon completion of the interview.

If you are a former International High School student who completed all four years at an International High School, graduated from an International High School between the years 2001-2013, completed an Associate's degree at a community college in the U.S., identify as Hispanic/Latino, and are interested in participating in this study, please review, sign, and return the consent form via e-mail at pmurillo@my.uri.edu. I will be setting up interviews shortly. If you have any 
questions or concerns about this study, you may contact Pamela Murillo, CoInvestigator, at (347) 495-0546. You may also contact Dr. Margaret Rogers, Principal Investigator, at mrogers@uri.edu. This research has been approved by The University of Rhode Island Institutional Review Board.

Thank you in advance for your participation!

Sincerely,

Pamela Murillo, M.A. (347) 495-0546

pmurillo@my.uri.edu

Doctoral Student

School Psychology Program

University of Rhode Island
Margaret Rogers, Ph.D.

(401) 874-7999

mrogers@mail.uri.edu

Full Professor

School Psychology Program

University of Rhode Island 


\section{Appendix E - Informed Consent Form}

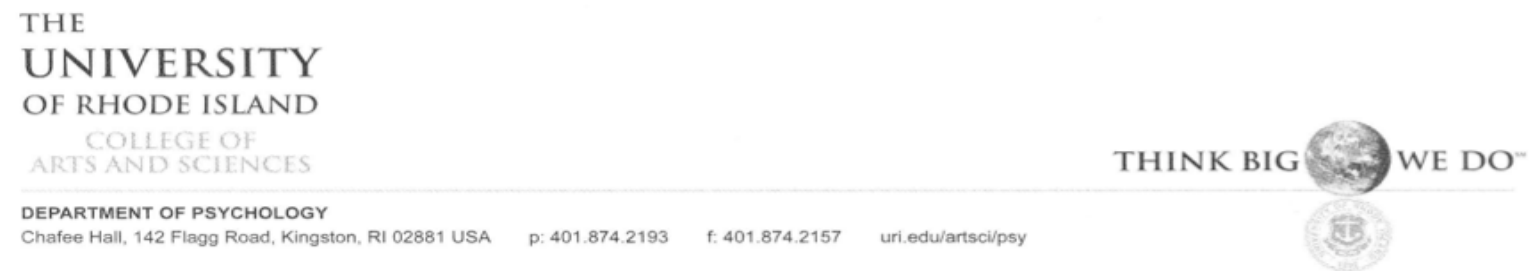

The University of Rhode Island

Department of Psychology

Kingston, RI 02881

The High School and Community College Experiences of Immigrant-English

Language Leaners

\section{CONSENT FORM FOR RESEARCH}

You have been invited to participate in a research project described below because you are a former International High School student who completed all four years at an International High School, graduated from an International High School between the years 2001-2013, completed an Associate's degree at a community college in the U.S., identify as Hispanic/Latino, and are interested in participating in this study. You are free to ask any questions you may have. If you have further questions or concerns, you may contact Pamela Murillo, Co-Investigator, at (347) 495-0546. You may also contact Dr. Margaret Rogers, Principal Investigator, at (401) 874-7999.

Description of the project:

This dissertation research study involves responding to a series of questions regarding your high school and community college experiences. More specifically, the interview will address questions about ways in which the International High School prepared you for college, as well as questions about the supports and challenges you experienced while working towards the completion of your Associate's degree. In addition, the interview will address questions about the implications of your second language abilities during college, reasons you think Hispanic immigrant-ELLs may stop at the Associate degree and do not continue through to the baccalaureate degree, as well as the type of advice you may have for other immigrant-ELLs to help them succeed in community colleges.

What will be done:

If you decide to participate in this study, you will take part in an audiotaped phone interview lasting about 30-45 minutes. A second interview will be scheduled only if supplementary information is needed or if technical difficulties arise during the interview. You will also receive a $\$ 20$ gift card as a thank you for your participation. 
Risks or discomfort:

The possible risks or discomforts of the study are minimal, although you may feel some embarrassment answering questions about your high school or college experiences.

Benefits of this study:

Although there will be no direct benefits to you, it is hoped that your experiences will help increase the knowledge base about supporting immigrant students while in community college.

Confidentiality:

Your participation in this study is strictly confidential. This means that none of the information will identify you by name and only pseudonyms will be used. All data will be maintained in a locked and secured facility, and will be kept for three years following completion of the study. In addition, all electronic data will be password protected and will be deleted three years following completion of the study.

Decision to quit at any time:

If you decide to take part in the study, you may choose to withdraw your participation at any time. There are no consequences for not participating in the study, and you are free to refuse to answer any questions.

Rights and complaints:

If you have any questions, or if you are not happy about the way in which this study is conducted, you may discuss your complaints with Pamela Murillo at (347) 495-0546 or Dr. Margaret Rogers at (401) 874-7999, anonymously, if you choose. In addition, if you have any questions about your rights as a research participant, you may contact the office of the Vice President of Research and Economic Development, 70 Lower College Road, Suite 2, University of Rhode Island, Kingston, Rhode Island, telephone: (401) 874-4328.

You have read this Consent Form and your questions have been answered. Your signature on this form means that you understand the information and you agree to participate in this study.

(Signature of interviewee)

(Printed name of interviewee)

(Date) 


\section{Audio Recording:}

I hereby give my consent for audio recording:

(Signature of interviewee)

(Printed name of interviewee)

(Date)

Enclosed are two copies of this consent form. Please keep a copy of this form and return a signed copy to Pamela Murillo via e-mail to pmurillo@my.uri.edu.

Thank you for your time and help in this study. Your assistance is greatly appreciated! 


\section{Appendix F - Statement on Diversity in Research}

This study included the recruitment of participants from diverse racial backgrounds, and males and females, to ensure that the findings were equally beneficial to the target population, which includes Hispanic/Latino immigrant-ELLs who attended an International High School and completed an Associate's degree.

The International High Schools are highly diverse, attracting adolescents from over 119 different countries who speak over 90 different languages (Internationals Network for Public Schools, 2016). The requirements to enter an International High School are to have lived in the U.S. for four years or less and to have scored in the bottom quartile on English language tests at the time of admission (Internationals Network for Public Schools, 2016). Approximately, 30\% of International High School students are undocumented and many are students with Interrupted Formal Education (SIFE) (Internationals Network for Public Schools, 2016). 


\section{Appendix G - Facebook Post}

ATTENTION International High School Graduates. If you are a former International High School student who completed all four years at an International High School, graduated from an International High School between the years 20012013, completed an Associate's degree in the U.S., and Identify as Hispanic/Latino, please e-mail me at pmurillo@my.uri.edu to inquire more information about your possible participation in my research study. My research study involves responding to a series of questions regarding your high school and community college experiences. If you choose to participate, you will take part in audiotaped phone interviews and will receive $\$ 20$ as a thank you for your participation. Any information you provide will be strictly confidential. Thank you so much! 


\section{Appendix H - Internationals Teachers' Preparation}

Teachers at the International High Schools undergo specific training provided by the International's Network Organization to assist them in their preparation of teaching immigrant-ELLs (Internationals Network for Public Schools, 2017). The training consists of a number of workshops that cover a range of topics pertaining to ELL education. The workshops include learning about the Internationals' approach, strategies for integrating language and content, strategies for working with a heterogeneous population, the student portfolio process and grading, the importance of fostering safe spaces and creating a welcoming community for students, as well as a number of academic strategies and interventions to help immigrant students succeed in school. The goal of the Internationals Network Organization is to prepare teachers to use collaborative learning as the predominant form of instruction so that students have multiple opportunities to interact and communicate with one another in English and in their native languages to discuss academic content. Teachers are encouraged to use students' native languages as a resource and incorporate projects that require students to read and write in their native languages into the curriculum (Internationals Network for Public Schools, 2017). 


\section{BIBLIOGRAPHY}

Alexander, B. C., García, V., González, L., Grimes, G., \& O'Brien, D. (2007). Barriers in the transfer process for Hispanic and Hispanic immigrant students. Journal of Hispanic Higher Education, 6(2), 174-184. doi:10.1177/1538192706297440

Anaya, G., \& Cole, D. G. (2001). Latina/o student achievement: Exploring the influence of student-faculty interactions on college grades. Journal of College Student Development, 42(1), 3. doi:10.1007/s10734-004-1705-4.

Bailey, T., Jeong, D. W., \& Cho, S. W. (2009). Referral, enrollment, and completion in developmental education sequences in community colleges. Economics of Education Review, 29, 255-270. doi:10.1016/j.econedurev.2009.09.002

Baker, R. W., \& Siryk, B. (1984). Measuring adjustment to college. Journal of Counseling Psychology, 31(2), 179-189. doi: 10.1177/0748175611400291

Baker, R. W., \& Siryk, B. (1989). Manual for student adaptation to college questionnaire. Los Angeles: Western Psychological Services.

Braun, V., \& Clarke, V. (2006). Using thematic analysis in psychology. Qualitative Research in Psychology, 3(2), 77-101. doi: 10.1191/1478088706qp063oa

Brilliant, J. J. (2000). Issues in counseling immigrant college students. Community College Journal of Research \& Practice, 24(7), 577-586. doi: $10.1080 / 10668920050139721$

Callahan, R. M. (2005). Tracking and high school English learners: Limiting opportunity to learn. American Educational Research Journal, 42(2), 305-328. 
Camic, P., Rhodes, J., \& Yardley, L. (2003). Qualitative research in psychology: Expanding perspectives in methodology and design (1st ed.). Washington, DC: American Psychological Association.

Cavanagh, S. (1997). Content analysis: Concepts, methods and applications. Nurse Researcher, 4(3), 5-13. doi: 10.7748/nr1997.04.4.3.5.c5869

Chávez, L. (2008). Untapped potential: Latinos and California community colleges. Policy Reports and Research Briefs, Center for Latino Policy Research, Institute for the Study of Social Change. Berkeley, CA: University of Caliornia, Berkeley.

Chickering, A. W., \& Reisser, L. (1993). Education and identity (2nd ed.). San Francisco: Jossey-Bass.

Clark, M. R. (2005). Negotiating the freshman year: Challenges and strategies among first-year college students. Journal of College Student Development, 46(3), 296-316. doi: $10.1353 / \mathrm{csd} .2005 .0022$

Cohen, A. M., \& Brawer, F. B. (2003). The American community college (4th ed.). San Francisco: Jossey-Bass.

Conchas, G. Q. (2006). The color of success: Race and high-achieving urban youth. New York, NY: Teachers College Press.

Conway, K. M. (2009). Exploring persistence of immigrant and native students in an urban community college. Review of Higher Education, 32(3), 321-352. doi: 10.1353/rhe.0.0059 
Conway, K. M. (2010). Educational aspirations in an urban community college: Differences between immigrant and native student groups. Community College Review, 37(3), 209-242. doi: 10.2190/CS.15.3.f

Conway, K. M. (2014). Critical quantitative study of immigrant students. New Directions For Institutional Research, 2013(158), 51-63. doi: 10.1002/ir.20045

Crisp, G., \& Mina, L. (2012). The community college: Retention trends and issues. In college student retention: Formula for student success. Lanham, MD: Rowman and Littlefield.

DiMaria, J. P. (2005). NEACRAO keynote speech. College and University, 80(4), $37-41$.

Erisman, W., \& Looney, S. (2007). Opening the door to the American dream: Increasing higher education and success for immigrants. Washington, DC: Institute for Higher Education Policy.

Fine, M., Jaffe, R., Pedraza, P., Stoudt, B., \& Futch, V. (2007). Swimming: On oxygen, resistance, and possibility for immigrant youth under siege. Anthropology and Education Quarterly 38(1), 76-96. doi: 10.1525/aeq.2007.38.1.76

Fine, M., Stoudt, B., \& Futch, V. (2005). The internationals network for public schools: A quantitative and qualitative cohort analysis of graduation and dropout rates: Teaching and learning in a transcultural academic environment. New York: The CUNY Graduate Center.

Gándara, P. (1999). Telling stories of success: Cultural capital and the educational mobility of Chicano students. Latino Studies Journal, 10(1), 38-54. 
Garcia, M. (2010). When Hispanic students attempt to succeed in college, but do not. Community College Journal of Research and Practice, 34(10), 839-847.

Goyette, K., \& Xie, Y. (1999). Educational expectations of Asian American youths: Determinants and ethnic differences. Sociology of Education, 72(1), 22-36. doi: $10.2307 / 2673184$

Graneheim, U. H., \& Lundman, B. (2003). Qualitative content analysis in nursing research: Concepts, procedures, and measures to achieve trustworthiness. Nurse Education Today, 24, 105-112. doi: 10.1016/j.nedt.2003.10.001

Gray, M. J., Vernez, G., \& Rolph, E. (1996). Student access and the "new" immigrants: Assessing their impact on institutions. Change: The Magazine of Higher Learning, 28(5), 41-47.

Hagy, A. P., \& Staniec, J. F. O. (2002). Immigrant status, race, and institutional choice in higher education. Economics of Education Review, 21(4), 381-392. doi: $10.1016 / \mathrm{S} 0272-7757(01) 00033-4$

Hale, E. D., Treharne, G. J., \& Kitas, G. D. (2007). Qualitative methodologies I: Asking research questions with reflexive insight. Musculoskeletal Care, 5(3), $139-147$.

Hao, L., \& Bonstead-Bruns, M. (1998). Parent-child differences in educational expectations and the academic achievement of immigrant and native students. Sociology of Education, 71(3), 175-198. doi: 10.2307/2673201

Hsieh, H. F., \& Shannon, S. E. (2005). Three approaches to qualitative content analysis. Qualitative Health Research, 15(9), 1277-1288.

Internationals Network for Public Schools. (n.d). Retrieved February $1^{\text {st }}, 2016$, from 
http://internationalsnps.org.

Jaffe-Walter, R., \& Lee, S. J. (2011). 'To trust in my root and to take that to go forward': Supporting college access for immigrant youth in the global city. Anthropology \& Education Quarterly, 42(3), 281-296. doi: 10.1111/j.15481492.2011.01132.x

Jensen, L., \& Chitose, Y. (1994). Today's second generation: Evidence from the 1990 U.S. census. International Migration Review, 28, 714-735.

Kessler, J. (2009). Oakland Unified School District case study: OIHS. Stanford, CA: School Redesign Network at Stanford University.

Kibler, A. K., Bunch, G. C., \& Endris, A. K. (2011). Community college practices for US-educated language-minority students: A resource-oriented framework. Bilingual Research Journal, 34(2), 201-222.

Kim, E., \& Díaz, J. (2013). Immigrant students and community colleges. ASHE Higher Education Report, 38(6), 91-107.

Koyama, J., \& Gibson, M. A. (2007). Marginalization and membership. In Van Galen, J. A. (Eds.). Late to class: Social class and schooling in the new economy (pp. 87-111). Thousand Oaks: SUNY Press.

Kvale, S. (1996). Interviews: An introduction to qualitative research interviewing. Thousand Oaks, CA: Sage.

Leinbach, D. T., \& Bailey, T. R. (2006). Access and achievement of Hispanics and Hispanic immigrants in the colleges of the City University of New York. New York, NY: Community College Research Center, Columbia University.

Lincoln, Y. S., \& Guba, E. G. (1985). Naturalistic inquiry. Beverly Hills, CA: Sage. 
Lopez, E. M. (1995). Challenges and resources of Mexican American students within the family, peer group, and university: Age and gender patterns. Hispanic Journal of Behavioral Sciences, 17(4), 499-508.

Lowell, B. L., Gelatt, J., \& Batalova, J. (2006). Immigrants and labor force trends: The future, past, and present. Task Force Insight, 17, 1-31.

McDonough, P. M., Antonio, A. L., \& Trent, J. W. (1997). Black students, Black colleges: An African American college choice model. Journal for a Just and Caring Education, 3(1), 9-36.

Murillo Jr. E. G., Villenas, S., Galván, R. T., Muñoz, J. S., Martínez, C., \& MachadoCasas, M. (Eds.). (2009). Handbook of Latinos and education: Theory, research, and practice. New York, NY: Routledge.

Murillo, P. (2015). Navigating college: The educational experiences of Hispanicimmigrant-English language learners. (Unpublished master's thesis). University of Rhode Island, Kingston, RI.

Nathan, R. (2005). My freshman year: What a professor learned by becoming a student. Ithaca, NY: Cornell University Press.

National Center for Education Statistics. (2007). The condition of education 2007 (NCES 2007-064). Washington, DC: U.S. Department of Education.

New York City Department of Education. (2009). New York City school progress report. New York: New York City Department of Education.

New York City Department of Education. (2013). New York City school progress report. New York: New York City Department of Education. 
Olsen, L. (1997). Made in America: Immigrant students in our public schools. Ithaca, NY: Cornell University Press.

Ornelas, A. (2002). An examination of the resources and barriers in the transfer function and process: A case study analysis of an urban community college. Unpublished doctoral dissertation, University of California, Los Angeles.

Orozco, G. L., Alvarez, A. N., \& Gutkin, T. (2010). Effective advising of diverse students in community colleges. Community College Journal of Research \& Practice, 34(9), 717-737. doi: 10.1080/10668920701831571

Pascarella, E., \& Terenzini, P. (2005). How college affects students: A third decade of research (Vol. 2). San Francisco, CA: Jossey-Bass.

Patten, E. (2012). Statistical portrait of the foreign-born population in the United States, 2010. Washington, DC: Pew Hispanic Center.

Portes, A., \& Rumbaut, R. G. (1996). Immigrant America: A portrait (2nd ed.). Los Angeles, CA: University of California Press.

Reynoso, N. A. (2008). Academic resiliency among Dominican English-language learners. Community College Journal of Research and Practice, 32(4-6), 391434.

Rivas, M. A., Pérez, J., Alvarez, C. R., \& Solórzano, D. G. (2007). An examination of Latina/o transfer students in California's postsecondary institutions (No. 16). Los Angeles: UCLA Chicano Studies Research Center.

Rodriguez, N., Mira, C. B., Myers, H. F., Morris, J. K., \& Cardoza, D. (2003). Family or friends: Who plays a greater supportive role for Latino college students? Cultural Diversity and Ethnic Minority Psychology, 9(3), 236-250. 
Rumbaut, R. G., \& Portes, A. (Eds.). (2001). Ethnicities: Coming of age in immigrant America. Berkeley, CA. and New York: University of California Press and Russell Sage Foundation.

Sandelowski, M. (2000). Whatever happened to qualitative description? Research in Nursing and Health, 23, 334-340. doi: 10.1002/1098240X(200008)23:4\%3C334::AID-NUR9\%3E3.0.CO;2-G

Seidman, I. (2006). Interviewing as qualitative research: A guide for researchers in education and the social sciences. New York, NY: Teachers College Press.

Sengupta, R., \& Jepsen, C. (2006). California's community college students. San Francisco, CA: Public Policy Institute of California.

Solberg, V. S., \& Viliarreal, P. (1997). Examination of self-efficacy, social support, and stress as predictors of psychological and physical distress among Hispanic college students. Hispanic Journal of Behavioral Sciences, 19(2), 182-201.

Solórzano, D. G., Rivas, M., \& Velez, V. (2005). Community college as a pathway to Chicana/o doctorate production. Latino Policy and Issues Brief \#11. Los Angeles, CA: UCLA Chicano Studies Research Center.

Suárez-Orozco, C., Suárez-Orozco, M. M., \& Todorova, I. (2008). Learning a new land: Immigrant students in American society. Cambridge, MA: Harvard University Press.

Sutherland, J. A. (2011). Building an academic nation through social networks: Black immigrant men in community colleges. Community College Journal Of Research And Practice, 35(3), 267-279. doi: 10.1080/10668926.2011.528665 
Szelenyi, K., \& Chang, J. C. (2002). Educating immigrants: The community college role. Community College Review, 32(2), 55-73.

Tao, S., Dong, Q., Pratt, M. W., Hunsberger, B., \& Pancer, S. M. (2000). Social support: Relations to coping and adjustment during the transition to university in the People's Republic of China. Journal of Adolescent Research, 15(1), 123144. doi: $10.1177 / 0743558400151007$

Teranishi, R. T., Suárez-Orozco, C., \& Suárez-Orozco, M. (2011). Immigrants in community colleges. Future of Children, 21(1), 153-169. doi: 10.1353/foc. 2011.0009

U.S. Census Bureau. (2007). Educational attainment of the population 15 years and over, by age, sex, race, and Hispanic origin. Retrieved January 26, 2016 from http://www.census.gov/ipc/www/usinterimproj.

U.S. Census Bureau. (2008). Enrollment status of the population 3 years old and over, by sex, age, race, Hispanic origin, foreign born, and foreign-born parentage. Retrieved January 20, 2016 from http://www.census.gov/ipc/www/usinterimproj.

U.S. Census Bureau. (2010). U.S. interim projections by age, sex, race, and Language. Retrieved January $5^{\text {th }}, 2016$ from http://www.census.gov/ipc/www/usinterimproj.

U.S. Department of Education. (2012a). The condition of education 2012 (NCES 2012-045).Washington, DC: National Center for Education Statistics.

Valenzuela, A. (1999). Gender roles and settlement activities among children and their immigrant families. American Behavioral Scientist, 42(4), 720-742. 
Vasquez, M. J. (1982). Confronting barriers to the participation of Mexican American women in higher education. Hispanic Journal of Behavioral Sciences, 4(2), 147-165.

Wells, R. (2010). Children of immigrants and educational expectations: The roles of school composition. Teachers College Record, 112(6), 6-7.

White, M. D., \& Marsh, E. E. (2006). Content analysis: A flexible methodology. Library Trends, 55, 22-45. doi: 10.1353/lib.2006.0053

Wild, L., \& Ebbers, L. (2002). Rethinking student retention in community colleges. Community College Journal of Research \& Practice, 26(6), 503-519.

Willig, C. (2001). Introducing qualitative research in psychology. Philadelphia, PA: Open University Press.

Wisell, T., \& Champanier, L. (2010). Community colleges as critical gateways for immigrant education. Diversity \& Democracy, 13(1), 16-17. 